\title{
Sociología de la imagen en Silvia Rivera Cusicanqui: conceptualización teórica y metodológica de una disciplina dialéctica, discursiva y rebelde
}

Sociology of the image in Silvia Rivera Cusicanqui: theoretical and methodological conceptualization of a dialectical, discursive and rebellious discipline

\author{
Claudio Díaz Herrera*
}

Resumen: Se reflexiona la configuración conceptual y metodológica de la sociología de la imagen, la cual converge con la postura epistemológica crítica de la autora. Principalmente a través del análisis de su obra y otros aportes en el tema, emerge una disciplina novedosa, holística, que recompone aspectos culturales indigenistas, feministas, valorizando una praxis rebelde y liberadora de lo subalterno, cuya reflexión representacional exige interiorizarse en una dimensión histórica, sociológica y antropológica del objeto de estudio.

Palabras claves: Sociología de la imagen, historia, cultura, pensamiento holístico.

\begin{abstract}
Abstrac: The conceptual and methodological configuration of the sociology of the image is reflected, which converges with the critical epistemological position of the author. Mainly through the analysis of her work and other contributions to the subject, a novel, holistic discipline emerges that recomposes indigenous, feminist cultural aspects, valuing a rebellious praxis that liberates the subaltern, whose representational reflection demands an interiorization in a historical, sociological and anthropological dimension of the object of study.
\end{abstract}

Keywords: Sociology of the image, history, culture, holistic thought.

Recibido: 4 agosto 2019 Aceptado: 8 diciembre 2019

${ }^{*}$ Chileno, Dr. (C) en Ciencias Humanas, sociólogo. Doctorado en Ciencias Humanas, Instituto de Estudios Humanísticos "Juan Ignacio Molina" y Facultad de Psicología, Universidad de Talca, Campus Talca, Chile. Artículo producto gracias a la beca de estudios doctorales Universidad de Talca. Correo electrónico: cldiaz@utalca.cl 


\section{Introducción}

\section{Inspiración de la sociología de la imagen en Silvia Rivera Cusicanqui}

El objeto del siguiente trabajo, es desarrollar una conceptualización que aporte a entender la noción teórica y metodológica de la sociología de la imagen según el trabajo de la socióloga, historiadora y activista boliviana Silvia Rivera Cusicanqui. Para lo anterior nos concentraremos en las obras por las cuales circunda esta preocupación disciplinaria de la sociología de la imagen en la activista social.

La sociología de la imagen en Bolivia, antes de ser considerada una disciplina científica como la podemos reconocer hoy, se elabora desde el siglo XIX con los trabajos del artista boliviano Melchor María Mercado, quien dibujaba rutas, paisajes sociales y culturales diversos de Bolivia, dando a conocer el mestizaje y prácticas económicas y políticas del país altiplánico boliviano. Posteriormente surge la figura de Jorge Sanjinés que rescata la temática indígena en Bolivia a partir de identificar una connotación imperante que describe como racista, violenta y de constante negación cultural ${ }^{1}$.

Para Rivera Cusicanqui, la sociología de la imagen es un oficio intelectual que surge gracias a sus inquietudes académicas con una convicción política y crítica. A su vez, se sustenta en sus recuerdos de niñez cuando la embargaba una inquietud por la imagen y particularmente la pintura ${ }^{2}$. En este sentido, su obra se configura plasmando una práctica en el quehacer intelectual y práctico ${ }^{3}$.

Según rescata Boaventura de Sousa Santos, el origen de la sociología de la imagen para la socióloga boliviana se encuentra en su propia práctica pedagógica e investigativa en los Talleres de Historia Oral Andina (THOA) y su ejercicio académico en educación superior. En este último espacio, con estudiantes de origen rural y marginal quienes tenían diversas dificultades en escritura, empero hablaban mejor, y sin lugar a dudas, miran mejor a como hablan 4 .

La sociología de la imagen en ella expresa una configuración que se orienta hacia la imagen con una labor que se encuentra llena de triunfos y fracasos, los que son conducidos desde la práctica y la academia en contacto con el mundo popular. De esta forma, existe en la autora una necesidad intrínseca de retribuir el conocimiento a las capas populares, desde donde se dispone a desarrollar diversas estrategias de comunicación, como teatro, radionovela e imagen, lo que termina por decantar en una sociología de la imagen ${ }^{5}$.

Otro elemento inspirador en Silvia Rivera Cusicanqui, es el tránsito desde el valor de la escritura hacia la imagen. Esto se produce por el desencanto provocado gracias al uso de la palabra por las clases políticas bolivianas, quienes terminaron por legitimar la noción

\footnotetext{
1 Silvia Rivera Cusicanqui, "Experiencias de montaje creativo: de la historia oral a la imagen en movimiento ¿Quién escribe la historia oral?", Chasqui. Revista Latinoamericana de Comunicación, (120), 2012, 14-18.

2 Silvia Rivera Cusicanqui, "I Love the Mountain", Afterall, 44, 2017, 144-149.

${ }_{3}$ Silvia Rivera Cusicanqui, Sociología de la Imagen: Miradas ch ixi desde la historia andina, Buenos Aires, Tinta limón, 2015.

4 Silvia Rivera Cusicanqui \& Boaventura de Sousa Santos, "Conversa del mundo", En Boaventura de Sousa Santos, Revueltas de indignación y otras conversas, 80-123, Bolivia, ALICE, 2015.

${ }^{5}$ Rivera Cusicanqui, Sociología de la Imagen... op. cit.
} 
dominante neoliberal, pero desde un discurso pluricultural. De esta forma, la clase política configuró un sentido de multiculturalidad que finalmente se transformó en una categoría político-cultural instrumentalizada por dicha clase dominante ${ }^{6}$.

Por tanto, el uso de la imagen no es inocuo. Rivera Cusicanqui da cuenta de ello inspirada en los análisis de Barthes de 1995, donde se plantea que existen estrategias de representación dentro de los cuales pueden ser usados ciertos mecanismos como por ejemplo: el uso de una particular selección de imágenes, un tipo de encuadre de una imagen en cuestión, el tipo de comentario adjunto al alero de una iconografía, así como una sintaxis del montaje logrado sobre una página en particular7.

\section{Aspectos epistemológicos y teóricos}

Si bien los antecedentes de la sociología de la imagen se encuentran dentro de la práctica académica con estudiantes rurales y de formas precarias de capital cultural, social y material, los educandos demuestran una gran capacidad de observar detalles, con atención creativa y precisa. De esta forma se revela la imagen como un recurso de observación analítica capaz de detectar imprecisiones históricas, pero las cuales requieren de una interpretación conceptual a partir de este conocimiento histórico de los hechos, ya que, no estamos alfabetizados para leer el bombardeo de imágenes colonizadoras ${ }^{8}$.

En la sociología de la imagen de Silvia Rivera, opera un necesario tránsito desde la escritura al montaje de las imágenes. En este último, subyacen aspectos subjetivos, reflexivos, teóricos, la experiencia como sujetos investigadores y creadores de una episteme. Este tipo de trabajo permite el uso de diferentes fuentes así como abrirse a sus variadas combinaciones de uso, siempre con el objeto de dilucidar un patrón, un común denominador que refleje desde el pasado una nueva lectura de sentido para el presente ${ }^{9}$.

El origen del trabajo desde la sociología de imagen se encuentra en la configuración de la historia oral y la necesidad de la comunicación de pueblos dominados. En este sentido, la imagen amparada en formato guion de ficción y documental es un intento “expresivo y racional, de seguir indagando en el tejido de lo social, pero a través de personajes construidos en la singularidad de sus dramas cotidianos"10. Para la autora, el análisis de la imagen es clarificadora por sobre el recurso textual, por la capacidad de poder dilucidar arquetipos de conducta colectiva con mayor precisión, revelando brechas y silencios en el ámbito de la cultura de los dominantes y los dominados que atraviesa la temporalidad social, denotando que los tiempos poseen prácticas de reproducción cultural y que por tanto la temporalidad da cuenta de similitudes que se hace necesario desnudar.

No podemos desconocer que, desde su origen intelectual y activista Silvia Rivera Cusicanqui ha desarrollado un pensamiento epistémico que desafía lo dominante, lo

\footnotetext{
6 Sinclaire Thomson, "Claroscuro andino: Nubarrones y destellos en la obra de Silvia Rivera Cusicanqui", En Silvia Rivera Cusicanqui, Violencias (re) encubiertas en Bolivia, 7-23, La Paz, Piedra roja, 2010.

7 Silvia Rivera Cusicanqui, “Construcción de imágenes de indios y mujeres en la iconografía post 52: el miserabilismo en el Álbum de la Revolución”, T'inkazos, (19), 2005, 133-156.

8 Rivera Cusicanqui \& Boaventura de Sousa, op. cit.

9 Silvia Rivera Cusicanqui, "Experiencias de montaje creativo: De la historia oral a la imagen en movimiento". En Silvia Rivera Cusicanqui, Violencias (re) encubiertas en Bolivia, 225-233, La Paz, Piedra Rota, $2010 \mathrm{~b}$.

10 Ibid., 226.
} 
tradicional, volcándose a una praxis en el sentido militante y dialéctico del concepto. Un desarrollo de su quehacer intelectual que converge con la transformación del espacio y medio a través del lenguaje, la imagen, lo simbólico y por tanto político. Ya nos adelanta nuestra socióloga boliviana que la sociología de la imagen la entiende como un "invernadero de experimentación pedagógica" que desarrollara en el Taller de Historia Oral Andina ${ }^{11}$.

De esta forma, la intelectual paceña se expresa desde una crítica ante los dilemas que produce la escritura, ya que, a diferencia de lo pictórico, la escritura siguió un camino totalizador, caracterizado por una composición lineal y tendiente a una gran narrativa integradora que pretende borrar las voces subalternas en pro de un discurso integrador y modernizador ${ }^{12}$. En definitiva, los imaginarios y la mirada resulta una herramienta para conocer desde una perspectiva crítica el mundo social ${ }^{13}$.

En este sentido, la sociología de la imagen no solo ofrece una analogía de la realidad como los plantearía Barthes ${ }^{14}$, sino más bien un recurso interpretativo de lo social, rescatando su heterogeneidad y el conflicto social ${ }^{15}$.

El valor de la imagen como un factor que traspasa las fronteras de la temporalidad y que si bien puede ser una expresión simbólica del pasado, emerge reveladoramente en el presente $^{16}$. La imagen se revela como un elemento transgresor que da una apertura a la reflexión del momento en el cual estamos situados en respuesta a la dominación y discurso oficial de predominancia fálica, machista y al Estado opresor que lo protege ${ }^{17}$.

El estudio de las imágenes da cuenta de lo que está subsumido, invisibilizado pero contextualizado a razón de quien lo plasma estéticamente. De esta forma existe un discurso asociado que transita entre la imagen y la palabra ${ }^{18}$. En términos de Rivera Cusicanqui, la sociología de la imagen es un aporte a la comprensión de lo social, el que "revela y reactualiza muchos aspectos no conscientes del mudo social"19

La sociología de la imagen se propone como un esfuerzo histórico interpretativo que logra complejizar la observación de los procesos sociales, por tanto es un aporte

\footnotetext{
11 Rivera Cusicanqui, Sociología de la Imagen... op. cit., 14.

12 Silvia Rivera Cusicanqui, Invisible Realities: Internal Markets and Subaltern. Identities in Contemporary Bolivia, Amsterdam/Quezon City, SEPHIS-SEASREP, 2005.

13 Silvia Rivera Cusicanqui, "Reflexiones en torno a la presente edición”. En Silvia Rivera Cusicanqui, Violencias (re) encubiertas en Bolivia, 25-30, La Paz, Piedra Rota, 2010c.

14 Roland Barthes, Lo obvio y lo obtuso. Imágenes, gestos, voces, Barcelona, Paidos, 1995.

15 Rivera Cusicanqui, Invisible Realities... op. cit.

16 Ana Cacopardo, "Nada sería posible si la gente no deseara lo imposible. Entrevista a Silvia Rivera Cusicanqui", Andamios, 15, (37), 2018, 179-193.

17 Silvia Rivera Cusicanqui \& Virginia Aillón Soria, “Introducción. Desde los márgenes. Pensadoras y pensadores bolivianxs de la diáspora". En Silvia Rivera Cusicanqui, \& Virginia Aillón Soria, Antología del pensamiento crítico boliviano contemporáneo, 13-39, Buenos Aires, CLACSO, 2015.

18 Silvia Rivera Cusicanqui, Ch'ixinakax utxiwa: una reflexión sobre prácticas y discursos descolonizadores, Buenos Aires, Tinta Limón, 2010.

${ }^{19}$ Héctor Parra, “La sociología de la imagen como anclaje crítico descolonizador. Aportes desde el movimiento indianista katarista de Bolivia", Extravío. Revista electrónica de literatura comparada, 8, 2015, 58-71, 61.
} 
teórico y metodológico que la autora ha desarrollado transversalmente y con versatilidad de énfasis en varias de sus obras ${ }^{20}$.

El uso de la imagen exige una comprensión subjetiva e intersubjetiva de la realidad en su contexto histórico y cultural que debe ser reconocido. Esta imagen posee un contenido discursivo relevante que debemos aprender a identificar y analizar desde esta subjetividad e intersubjetividad con habilidad holística, de lo contrario se pueden asumir alegorías discursivas que inducen el anclaje de representaciones simbólicas dominantes y colonizadoras, en desmedro de un entendimiento alternativo de otras realidades en el mundo de la vida ${ }^{21}$.

Para Silvia Rivera Cusicanqui, esta sub disciplina de la sociología aporta a la comprensión del mundo social revelando y actualizando aspectos que no son conscientes. La imagen es capaz de ofrecer una interpretación y narración de lo social para su comprensión crítica, así como la capacidad de develar un sentido que no está censurado por el discurso oficial, según la época en la cual se retrata una representación simbólica que no necesariamente debe ser descrita sino más bien interpretada ${ }^{22}$.

De esta forma para la autora emerge el desafío metodológico y más aún analítico de un abordaje iconográfico. En este sentido, la descripción puede estar teñida de discursividad que debemos aprender a desentrañar y paralelo a esto, la sociología de la imagen en Rivera Cusicanqui exigiría de esta inteligencia sociológica cultural, social, política e histórica que coadyuve con lucidez hacia la interpretación legitimadora de la subalternidad.

El análisis de la imagen nos puede develar cómo hacer frente al colonialismo a partir de formas por las cuales se ha expresado. Podemos en tanto identificar desde el pasado una reapertura objetiva que es pretendida en el presente y que tiene la virtud de reabrir espacios de problematización y desmitificación ${ }^{23}$. R. Cusicanqui expone el sentido de la subalternidad en relación a los antagonismos, más allá de buscar una suerte de consenso o complementariedad. Si bien reconoce el valor simbólico de la diferencia, la socióloga boliviana no descarta la tensión del conflicto la cual propone como elemental para configurar un espacio analítico y explicativo del presente, por tanto posee un valor multidireccional en este trabajo longitudinal en términos temporales ${ }^{24}$.

A su vez, la sociología de la imagen "considera a todas las prácticas de representación como su foco de atención; se dirige a la totalidad del mundo visual" (p. 21), colocando atención a diversas expresiones visuales y representaciones colectivas del espacio social. En consecuencia, en la imagen hay memoria por recuperar que se expresa a través de la acción, del lenguaje y la escritura que debe ser descolonizado para su

\footnotetext{
20 Romina Accossatto, “Colonialismo interno y memoria colectiva. Aportes de Silvia Rivera Cusicanqui al estudio de los movimientos sociales y las identificaciones políticas", Economía y Sociedad, XXI, (36), 2017, 167181.

21 Silvia Rivera Cusicanqui, Dis/Locating Culture: Narratives and Epistemologies of Displacement. A stroll through the Colonial Library", 9, Huston, Rice University, 2011, Consultado 12 de junio de 2019. Disponible en: https://www.academia.edu/7338101/A_stroll_through_the_Colonial_Library

22 Rivera Cusicanqui, Ch'ixinakax utxiwa:... op. cit.

23 Idem.

${ }^{24}$ Melisa Stocco, "El concepto de taypi ch'ixi como aporte al estudio de la poesía mapuche bilingüe". Mundo Amazónico, 9, (1), 2018, 87-103.
} 
liberación corporal, mental y sensorial con el objeto de transgredir las estructuras y condiciones normativas que no permiten esta liberación ${ }^{25}$.

No podemos dejar de mencionar la irreverencia con la cual la paceña en su construcción epistémica y teórica, un desafío a las fronteras disciplinarias ${ }^{26}$ que las ciencias sociales tanto han cuestionado como objeto de estudio a pesar de compartir independiente de la disciplina en ejercicio, tantas similitudes a partir del sujeto de estudio como fuente principal científico social 27.

Para su aplicación en la sociología de la imagen, el uso de la historia en Rivera Cusicanqui nos hace recordar los planteamientos clásicos de Wrigth Mills respecto a la imaginación sociológica. En dicho texto el autor coloca de manifiesto su crítica a la sociología contemporánea de su época la cual a su juicio no se enfocaba con certeza en relación a las preocupaciones de las ciencias sociales, las cuales debe tratar temáticas relacionadas con la biografía e historia dentro de las estructuras sociales. Sin ir más lejos y en sus propias palabras:

"los estudios a-históricos tienden por lo general a ser estudios estáticos, o a muy corto plazo, de ambientes limitados. No puede esperarse otra cosa, porque conocemos más fácilmente las grandes estructuras cuando cambian, y probablemente llegamos a conocer esos cambios únicamente cuando ensanchamos nuestra visión hasta abarcar histórico suficiente" 28 .

Es relevante hacer una distinción entre sociología de la imagen y antropología visual, la cual resulta compleja si lo analizamos en relación a una discusión respecto a las fronteras disciplinarias en la configuración del objeto de estudio en ciencias sociales, problematizando entonces en la distancia sujeto/objeto de las disciplinas. Otra de las diferencias dice Rivera Cusicanqui, es que la antropología visual orienta el registro en imágenes de las sociedades estudiadas para ser expuestas a un público como una suerte de "práctica de representación".

La sociología de la imagen se remite, como ya hemos visto, al valor de la historia alternativa. A su vez, las enunciaciones nos evocan una pluralidad de significados que la historia posee según el sujeto quien construye la narración y que hacen sentido a razón del variado uso de lenguas en una sociedad particular, en su caso boliviana. De esta forma se constituye a través de la imagen y otros recursos visuales, múltiples vías de acceso a su comprensión, apartándose de una linealidad explicativa, sino más bien hacia el reconocimiento de realidades múltiples en un contexto en particular ${ }^{29}$.

Silvia Rivera apuesta al fin de una era racionalista predominante, dentro de la cual categorías analíticas provenientes de la imaginación, las emociones, las pasiones, las identidades construidas y en construcción, la persona como representación social, rompe justamente con un esquema racional de ser humano consciente y que se enarbola como un

\footnotetext{
25 Rivera Cusicanqui, Sociología de la Imagen... op. cit.

26 Cacopardo, op. cit.

27 Carlos Pérez, Sobre un concepto histórico de ciencia, Santiago, Ediciones LOM, 1998.

${ }_{28}$ Charles Wrigth Mills, La imaginación sociológica, México D.F, F.C.E, 1986, 162.

${ }^{29}$ Rivera Cusicanqui, Invisible Realities... op. cit.
} 
contra plano que se enlaza con la comunicación ${ }^{30}$. En definitiva, Rivera apela a una sociología de la imagen con clara inspiración dialéctica, en el sentido de buscar las raíces históricas de la imagen en su contexto, no apelar a un determinismo causal de la explicación de los fenómenos, en relación a no separar los hechos de los valores que producen una sociología inhumana ${ }^{31}$.

\section{Aspectos metodológicos de la sociología de la imagen}

La sociología de la imagen posee una connotación práctica desde la vivencia de los investigadores, a razón de generar conocimiento en grupo, una práctica que Silvia Rivera Cusicanqui denomina "comunidades temporalmente autónomas", donde se realza la experiencia compartida entre investigadores y sujetos quienes forman parte del estudio ${ }^{32}$. Por tanto existe en la sociología de la imagen según la autora, una disposición hacia recrear un pasado vivo, resistente a la homogenización, a la occidentalización cultural y que recupere lo comunitario ${ }^{33}$.

El análisis de la imagen otorga una perspectiva cercana, aporta a romper con las fronteras lineales de la temporalidad entregándonos una representación cercana. Evita un simbolismo pintoresco en términos de encuadre ornamental, por tanto, es una imagen real, vívida en su contexto, de pasado tangible y proyectado, una imagen que está cercana al devenir del mercado, al capital, es dinámico y no solo una imagen estática de un cuadro fotográfico bien logrado 34 .

La categoría mestizaje se transforma en ella en una conceptualización central para entender la sociología de la imagen que desarrollará como propuesta metodológica y especificidad disciplinar desde el año 2000. A partir de los trabajos del mestizaje, la socióloga boliviana intenta reconstruir la representación social y simbólica que posee esta categoría en las clases dominantes y con la ayuda de imágenes logra comprender la temática que converge con prácticas en los sujetos ${ }^{35}$.

Por ejemplo, el caso del montaje en el cine es un recurso hipnotizador, ya que, puede servir como elemento de apertura reflexiva gracias a la construcción de una realidad que se reconstruye a razón de una composición de montajes de imágenes diversas que incita a una nueva significación. Lo anterior se sustenta en una suerte de "inutilidad" de la palabra y la "denuncia", que invita a generar otros mecanismos de atracción que logren captar la indignación moral colectiva ${ }^{36}$. Para la autora, el uso de la imagen a través del montaje pretende ser reflexivo, inspirador, conmociona y sacude al espectador ${ }^{37}$.

\footnotetext{
30 Silvia Rivera Cusicanqui, “Décoloniser la sociologie et la société”, Journal des anthropologues, (110-111), 2007, 249-265.

31 George Ritzer, Teoría sociológica clásica, Madrid, Mc Graw Hill, 2001.

32 Cacopardo, op. cit, 187.

${ }^{33}$ Rivera Cusicanqui, Invisible Realities... op. cit.

34 Idem.

35 Rivera Cusicanqui, "Reflexiones en torno...", op. cit.

36 Rivera Cusicanqui, "Experiencias de montaje creativo: de la historia oral a la imagen en movimiento ¿Quién escribe? op. cit.

37 Rivera Cusicanqui, "Experiencias de montaje creativo: De la historia oral a la imagen en movimiento", op. cit., 226.
} 
Existe un esfuerzo metodológico por detenerse con profundidad en los detalles. Como ella diría: "estoy en un universo de reivindicar el detalle, el fragmento y lo concreto desde mi práctica"38. Debemos ser conscientes de una crítica a una técnica de levantamiento de información intrusiva, violenta, avasalladora, por tanto es una fuente de inspiración para generar nuevas estrategias que estén más vinculadas a los sentidos, sin la necesidad de dominar lo observado, sino más bien una mirada horizontal, de iguales ${ }^{39}$. Se evidencia en las metodologías de la historia oral, que la imagen es un elemento clave en la reconstrucción de la memoria y la identidad, dentro de la cual, las imágenes entendidas como documentos no son necesariamente nuevas y por tanto, son de amplio espectro y forma ${ }^{40}$.

Como metodología, la imagen es un constructor crítico de narrativa, poseedora de un potencial denunciante de las distintas formas que asume el colonialismo en la actualidad, lo que permite a su vez relevar un sentido invisibilizado por la cultura dominante y lengua oficial, en el entendido que las palabras desde el colonialismo encubren más que develan y por otro lado, las palabras pueden perfectamente desconectarse de la práctica ${ }^{41}$. Emergen las voces subalternas para que puedan ser visibilizadas, representadas y por tanto escuchadas a raíz que se encuentran sub sumidas por la cultura colonizadora y dominante ${ }^{42}$.

Habría que reconocer en la autora, que la observación de estas fuentes de información van más allá de la connotación de "fuente" propuesta por la metodología clásica, desde la cual se pueden extraer ideas e interpretaciones generales de la sociedad, sino que aplicaría un tipo ideal weberiano de dicha fuente, en la cual se pueda interpretar en sí misma, en cuyos autores de estas fuentes aparte de representarse su realidad, se transforman en una voz que reflexiona sobre sí, interpretando y teorizando la realidad ${ }^{43}$.

Para Rivera Cusicanqui, la historia es un elemento trascendental en el análisis de los fenómenos sociológicos con potencial explicativo tal como lo plantearía el sociólogo alemán Max Weber; o bien la pretensión materialista dialéctica en Marx, por la cual se constituye la historia como uno de los referentes analíticos para desentrañar al ser humano en relación con su trabajo como tal, los medios del trabajo y el objeto del trabajo ${ }^{44}$.

\section{Análisis aplicado de la sociología de la imagen. El caso Miradas ch'ixi desde la historia andina}

Al margen de las obras escritas donde nuestro personaje desarrolla una conceptualización teórica y metodológica de la sociología de la imagen, existen otras obras las que aplica sintéticamente su saber sin entrar más allá de esta conceptualización, sino más bien las presenta como un análisis aplicado.

\footnotetext{
38 Cacopardo, op. cit, 193.

${ }^{39}$ Rivera Cusicanqui \& Boaventura de Sousa, op. cit.

40 Rivera Cusicanqui \& Aillón Soria, op. cit.

41 Rivera Cusicanqui, Ch'ixinakax utxiwa:... op. cit.

42 Rivera Cusicanqui, Invisible Realities... op. cit.

43 Idem.

${ }^{4}$ Ritzer, op. cit.
} 
A modo de ejemplo, Silvia Rivera, asumiendo un rol de dirección conceptual, compone en el libro "Principio Potosí Reverso". El texto es una cronología literaria que converge con la imagen inspirada en concepciones epistémicas del sur que son asumidas por la autora. En este sentido y haciendo uso de una cosmovisión multidimensional, el texto invita a ser leído partiendo por el centro del libro hacia la derecha, para luego volver al centro y proseguir la lectura hacia la izquierda del texto leído justamente hacia atrás ${ }^{45}$.

Para el caso del texto en particular que analizaremos, la autora realiza un estudio iconográfico de las acuarelas de Melchor María Mercado (1997), haciendo un esfuerzo asociativo del conjunto de estas obras pictóricas y que sistematizara en su libro don Gunnar Mendoza ${ }^{46}$.

Rivera comienza analizando esta obra, en la cual Mendoza realiza un recorrido genealógico por la obra de Melchor la cual estuvo atravesada por la precariedad y avatares políticos, contexto que dio cuenta en sus pinturas. Rivera escribe: "Su propio Álbum no es otra cosa que una demostración elocuente de estos procesos de cholificación que habrán de contribuir, no a la homogeneización de la sociedad, sino tan sólo a multiplicar sus estratos discriminados y excluidos" 47 .

Rivera interpreta en la obra del Melchor, que en sus pinturas desea configurar una imagen de pertenencia boliviana; estimular el imaginario nacionalista de la elite republicana y la consideración del territorio como patrimonio.

A juicio de nuestra autora, Melchor María Mercado enfatiza en una noción de lo boliviano a través de un tránsito en los oficios y hábitos andinos, empatizando con la marginalidad de la población, su cultura, festividades, las actividades laborales y reflexionando desde lo mestizo e indígena. Por tanto, es una suerte de estudio cultural, etnográfico, que colinda con los márgenes, lo inhóspito, lo salvaje.

Para ella, la secuencia de pinturas tiene la intención de documentar la república boliviana entre 1841 y 1869 mediante una composición de trayectorias con discurso plástico y de significación vigente hasta el día de hoy. De esta forma la autora en su libro, analiza este apartado con tres secuencias del álbum de pinturas, la primera con personas en actitud de "trajín" hacia Potosí y La Paz como visión de una trayectoria ciudadmercado; la segunda como trayectoria secuencial de iglesia-barco-montaña-iglesia de su etapa en Sorata (ciudad boliviana); y finalmente con una etapa que más allá de lo documental hace fluir al Melchor artista.

Fiel a su formación disciplinaria en ciencias sociales, analiza las láminas con agudeza histórica y sociológica, apelando a la comprensión de lo plasmado en pinturas desde una entrenada inteligencia sociológica, con una visión holística que le permite observar a través de la imagen. Interpreta en las obras de Melchor la preocupación por plasmar estéticamente las relaciones y prácticas cotidianas de esta Bolivia emergente en su República, demostrando la distinción y jerarquización de clases, ropas, orígenes étnicos, mestizajes, la fiesta, la segregación, el proceso de cholificación urbana, el mundo cholo como "tercera república", la articulación territorial con un tránsito marcado entre los valles, las

45 Silvia Rivera Cusicanqui \& El colectivo (dirección), Principio Potosí Reverso, Madrid, Museo Nacional Reina Sofía, 2010.

46 Rivera Cusicanqui, Sociología de la Imagen... op. cit.

47 Ibid., 36. 
minas y las ciudades. Retrata así una simbología indígena que se trasviste en los retratos de fiesta, haciendo posible la relación inter castas que se encuentra bloqueada en el diario vivir.

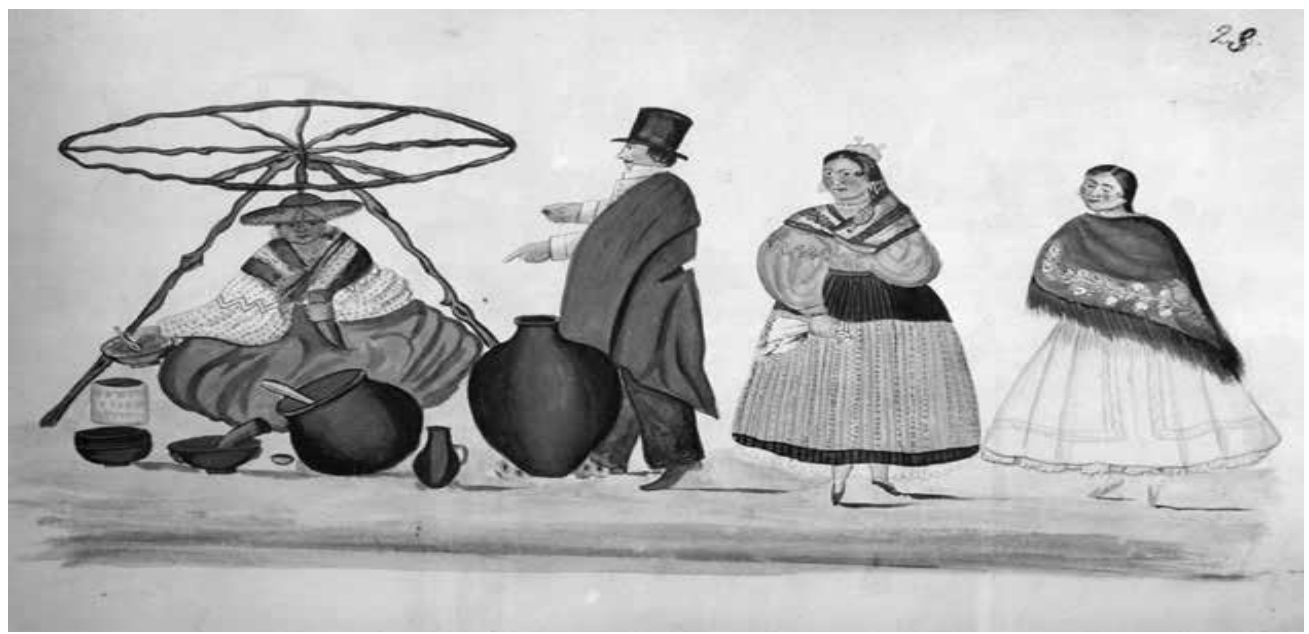

Imagen 1.- Lámina 23 “Vendedora y otros tipos populares (Potosí)”, Fuente: Rivera Cusicanqui, 2015, 44.

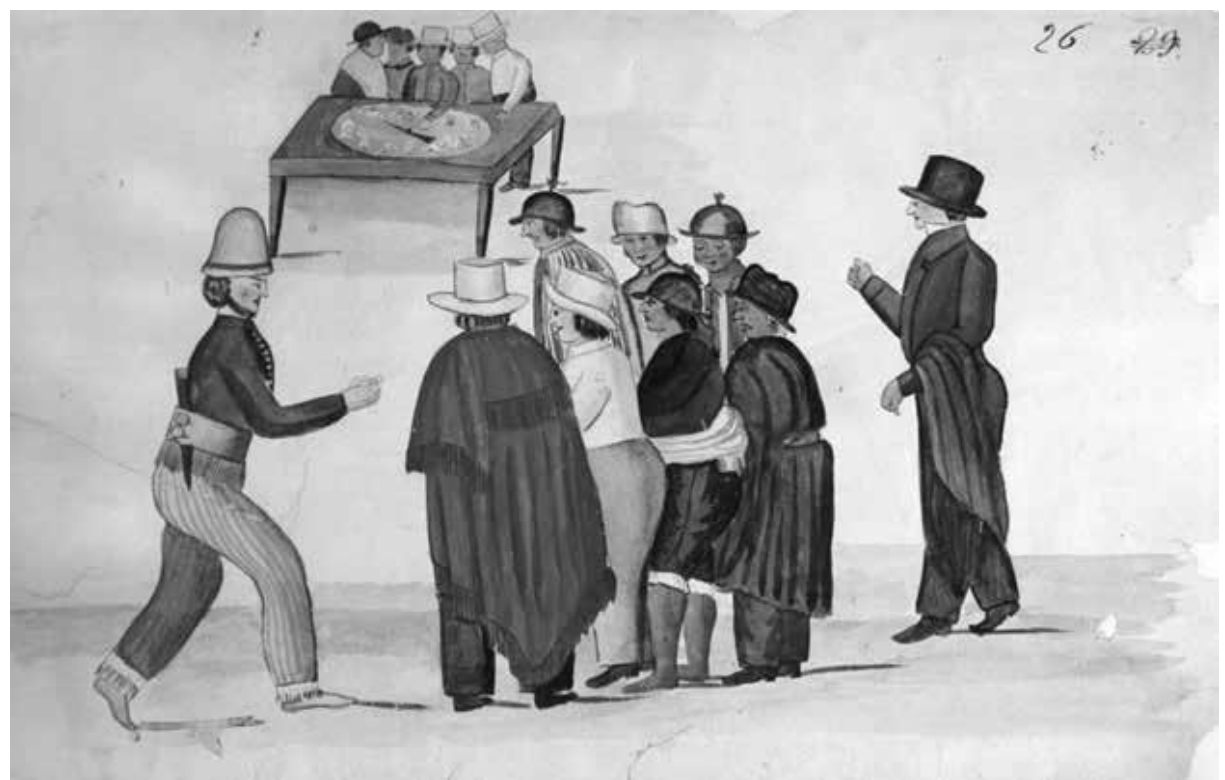

Imagen 2.- Lámina 26 “La ruleta”, Fuente: Rivera Cusicanqui, 2015, 44. 


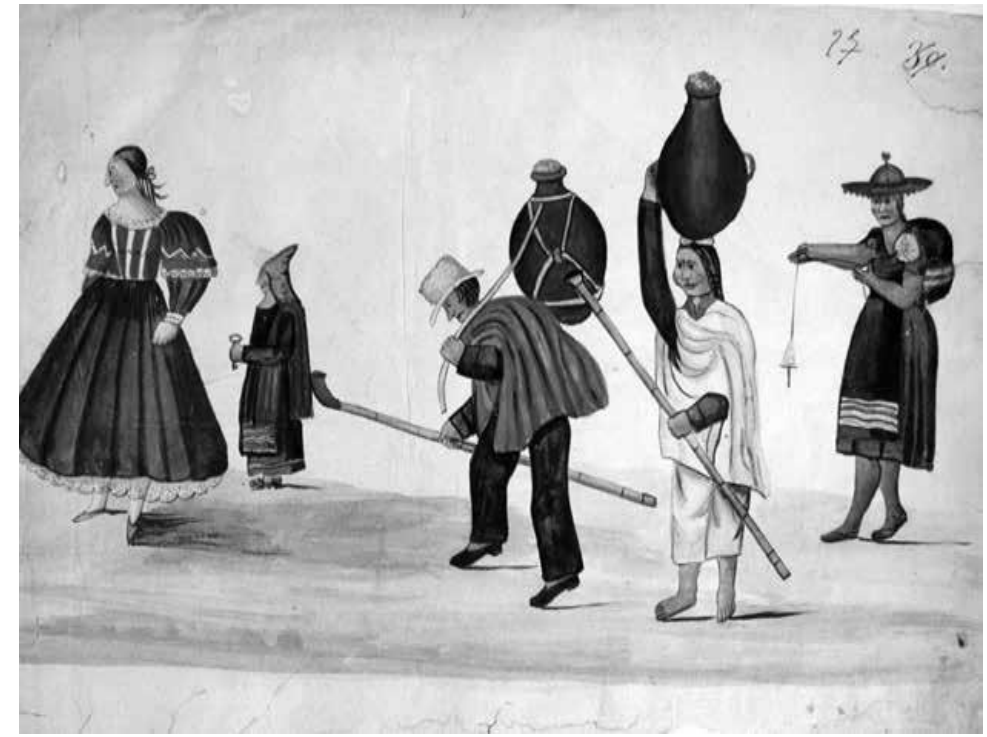

Imagen 3.- Lámina 27 “Transporte de chicha”, Fuente: Rivera Cusicanqui, 2015, 45).

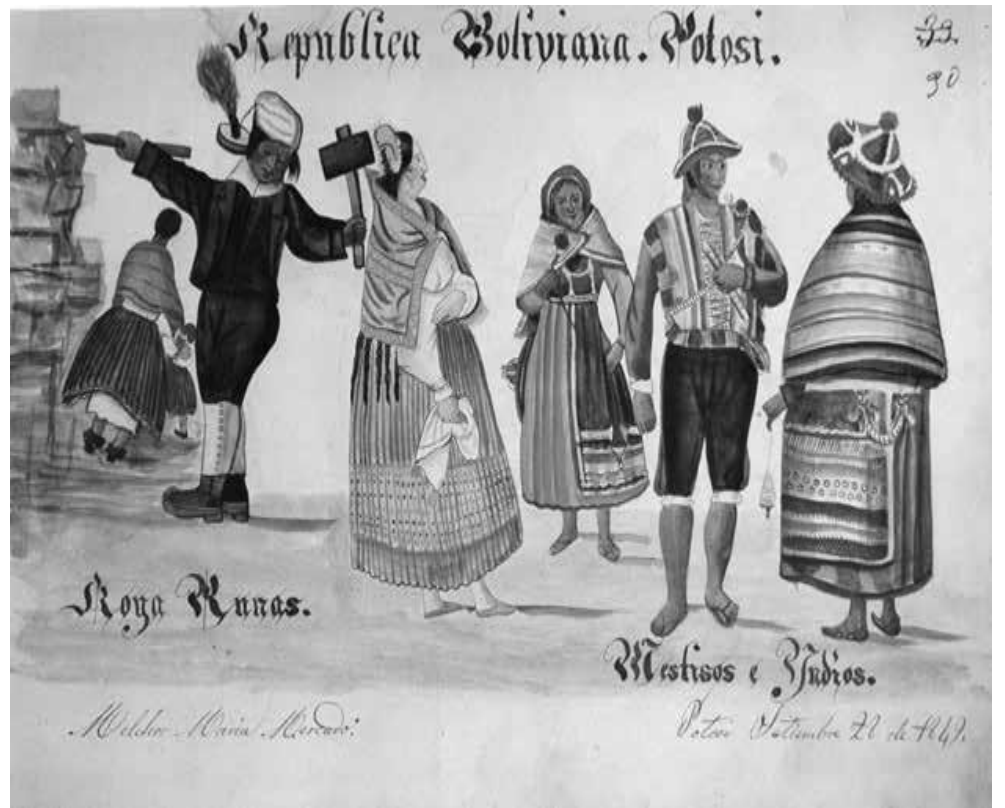

Imagen 4.- Lámina 30 “Republica Boliviana. Potosí. Koya runas. Mestizos e indios” Copia de Alcided'Orbigny, Fuente: Rivera Cusicanqui, 2015, 47. 


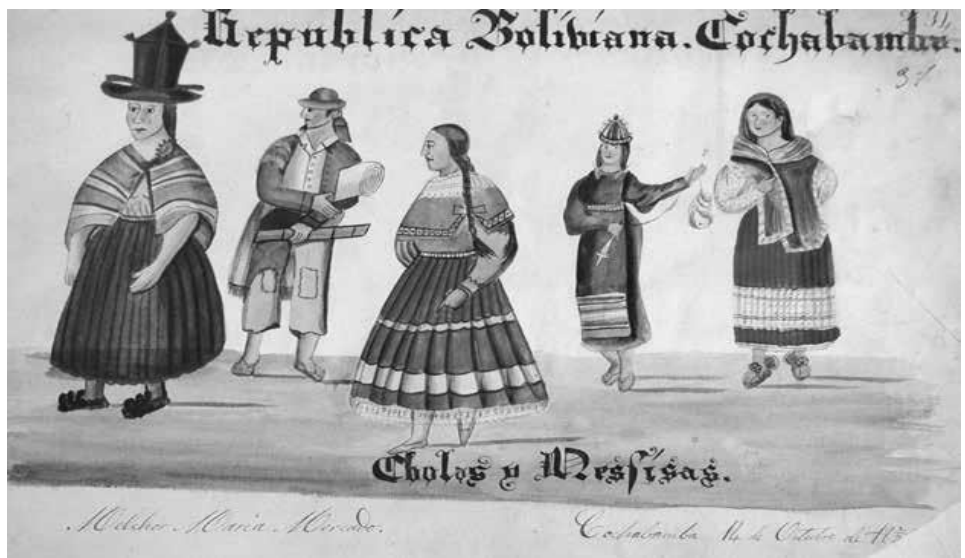

Imagen 5.- Lámina 31 “República Boliviana. Cochabamba. Cholas y Mestizas”, Fuente: Rivera Cusicanqui, 2015, 47.

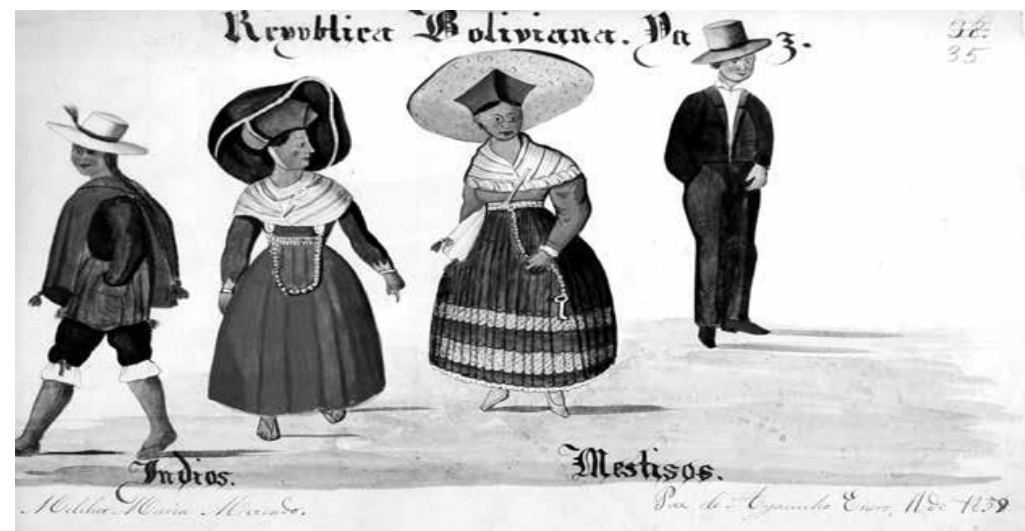

Imagen 6.- Lámina 35 “República Boliviana. Paz. Indios. Mestizos”, Fuente: Rivera Cusicanqui, $2015,49$.

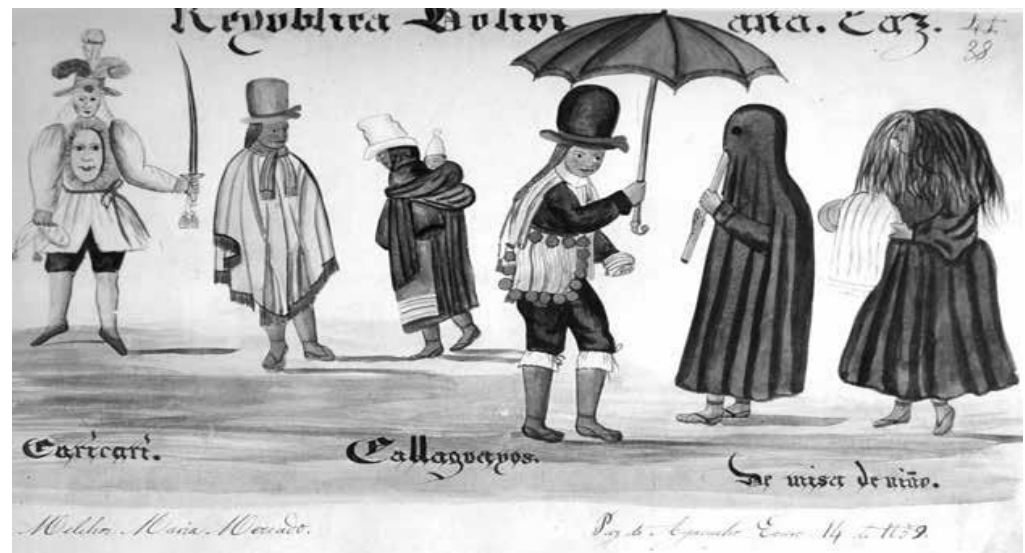

Imagen 7.- Lámina 38 “República Boliviana. Paz. Caricari. Callaguayos. De misa de niño”, Fuente: Rivera Cusicanqui, 2015, 51. 


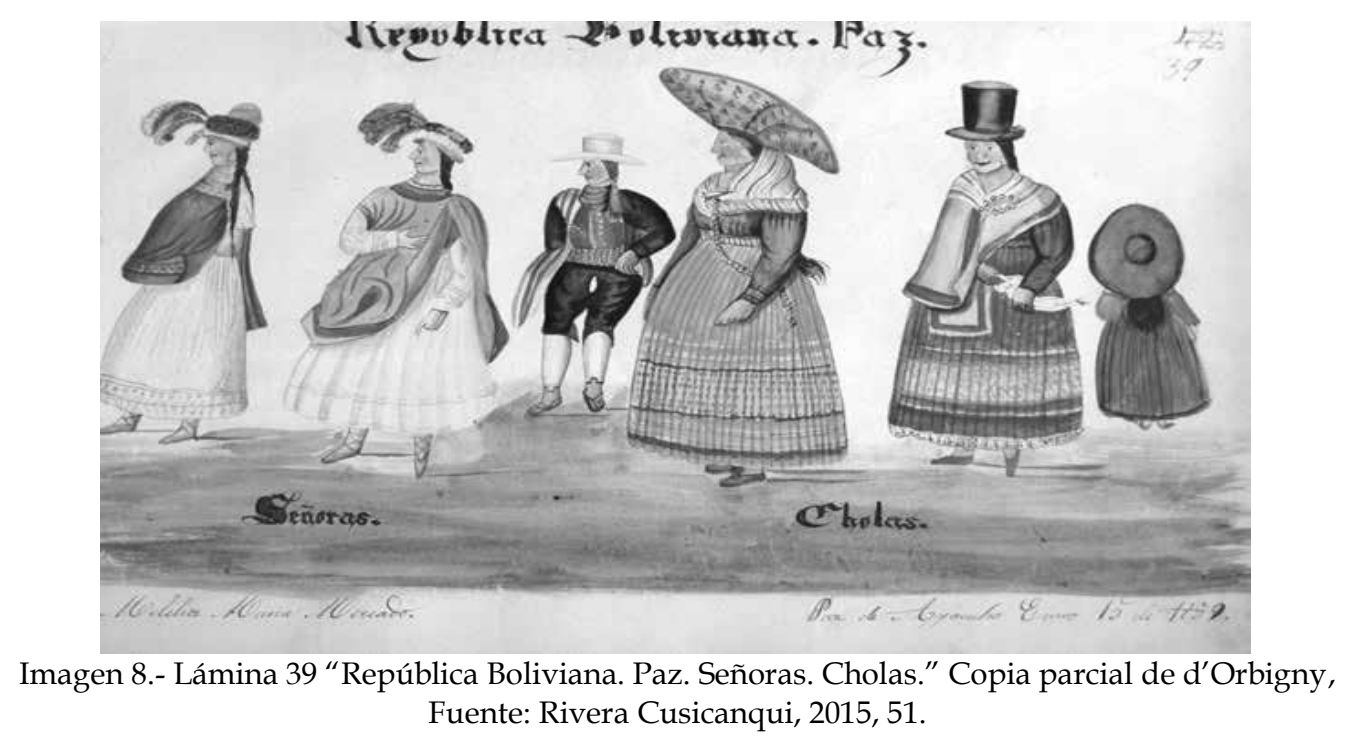

En el sub capítulo "la simbología e iconografía del poder" destaca la llamada "Etapa de Sorata". Aquí Mercado retrata iglesias, veleros y montañas, donde destaca a su vez, la ausencia de la figura humana.

En un análisis asociativo de la imagen de Silvia Rivera, la autora interpreta los intentos por representar el poder político regional dentro del marco de las relaciones entre Bolivia, Chile y Perú, en cuyas láminas se puede visualizar una suerte de antagonismo entre lo superior e inferior, destacando puertas sin una base que las sustentes o un flamear de banderas peruanas, es decir, encontramos trazos prolijos en lo superior y trazos difusos en lo inferior, dándole así una relevancia a una direccionalidad norte-sur que se plasma a nivel geográfico y simbólico.

En este sentido pareciera haber un trazo asociativo de inicio y fin. Silvia escribe: "al principio, las iglesias de Ayo-Ayo-Sicasica, y al final, las de Calamarca y Viacha. Parece que la divagación sobre el mar y los poderes relativos de Perú y Bolivia, se hubiese hecho a partir de un "corazón" productivo y social: la ruta troncal La Paz-Oruro, flanqueada por una espectacular sucesión de iglesias y montañas" 48 .

Hay en consecuencia una conexión simbólica entre la iglesia y montaña muy característica de la región andina, donde las torres de las construcciones de iglesias se funden con las cumbres montañosas, compartiendo en ambos espacios manifestaciones rituales como por ejemplo libaciones, abanderamientos y expresiones de poder político que fortalecen la relación peruana-boliviana, al alero de un nacionalismo que simboliza autoridad y poder político que se erige frente a otra joven nación como la chilena que se grafica con mayor envergadura como en el caso de la lámina 95.

48 Rivera Cusicanqui, Sociología de la Imagen... op. cit., 52. 


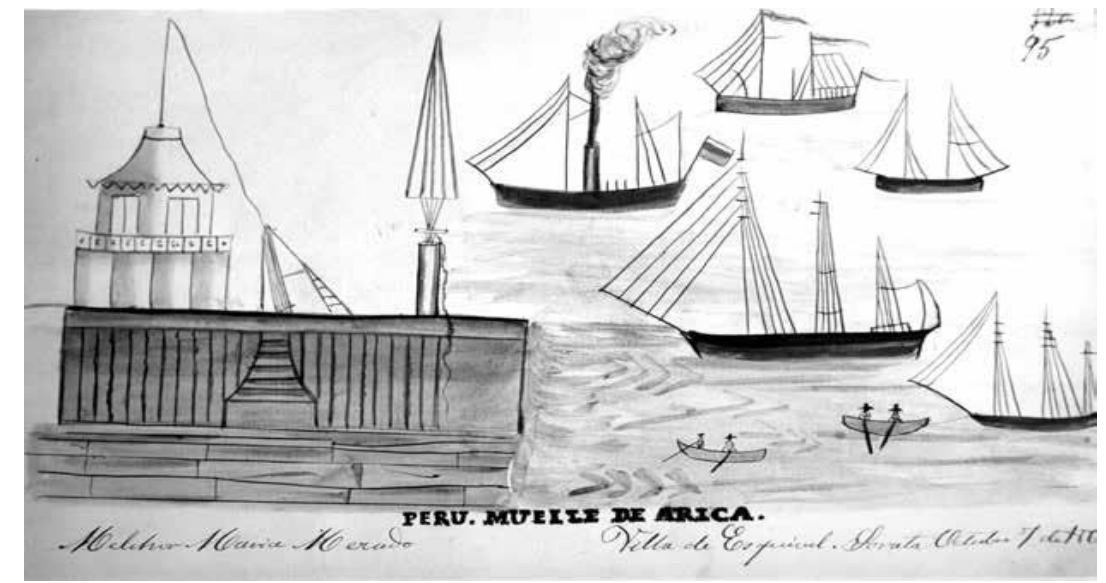

Imagen 9.- Lámina 95 “Perú. Muelle de Arica”, Fuente: Rivera Cusicanqui, 2015, 60.

Lo anterior nos da la idea a juicio de Silvia Rivera Cusicanqui, que Mercado antes de la guerra del Pacífico ya:

“imaginara a Bolivia y el Perú bajo la amenaza de un conflicto latente, que se cernía sobre los paisajes y pobladores descritos en su Álbum. La estereotipada representación de las banderas peruanas (Lámina 89, 94, 96) y la exageración de sus dimensiones vehicula una idea obsesiva de soberanía, o el anhelo de algún poder protector que permitiera al Perú mantener la integridad de su territorio. Las imágenes de los cerros cumplen una función similar con respecto a Bolivia: emblema protector de una heredad amenazada; razón de existir de la comunidad imaginada Bolivia, inscrita en un pasado anterior a la historia" 49.

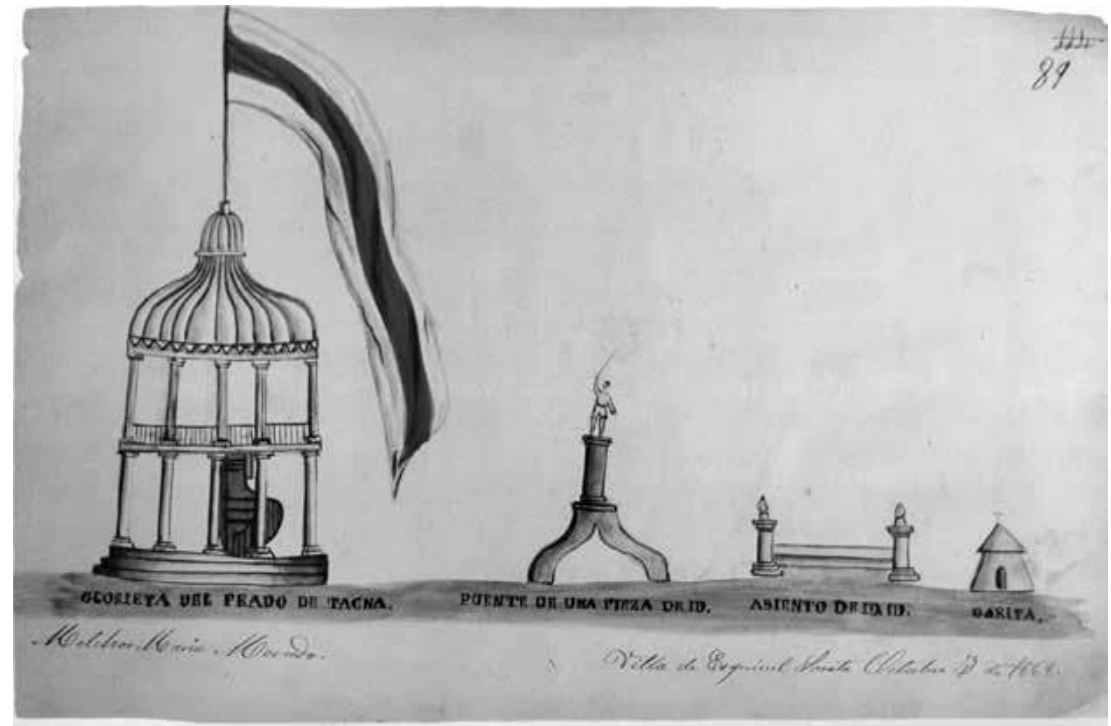

Imagen 10.- Lámina 89 "Glorieta del Prado de Tacna. Puente de una pieza de id. Asiento de id. Id. Garita", Fuente: Rivera Cusicanqui, 2015, 57.

49 Rivera Cusicanqui, Sociología de la Imagen ... op. cit., 53, 54. 


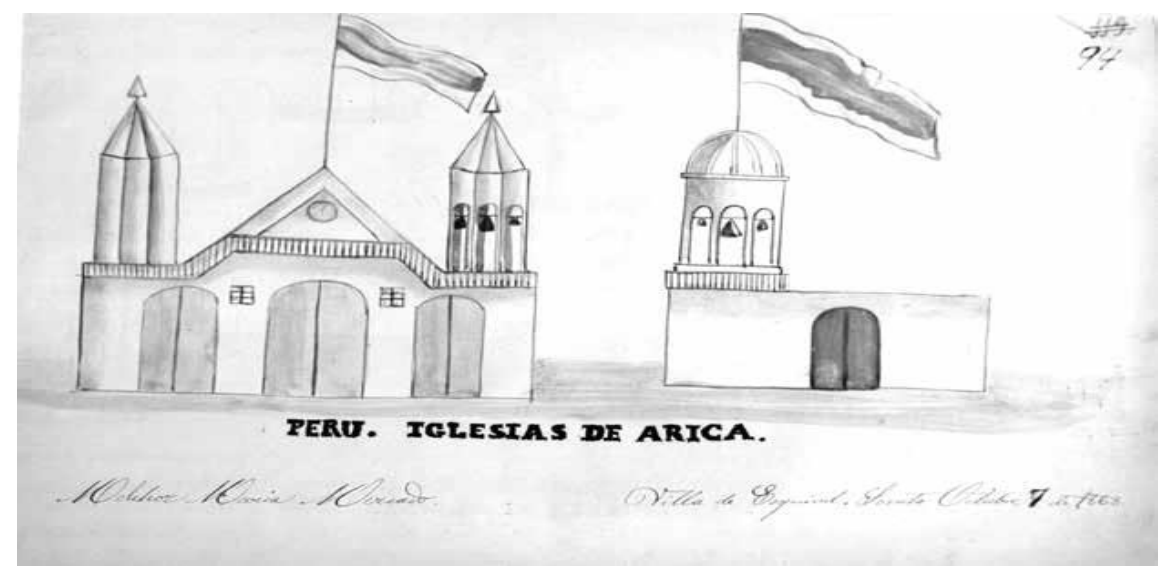

Imagen 11.- Lámina 94 "Perú. Iglesias de Arica", Fuente: Rivera Cusicanqui, 2015, 59.

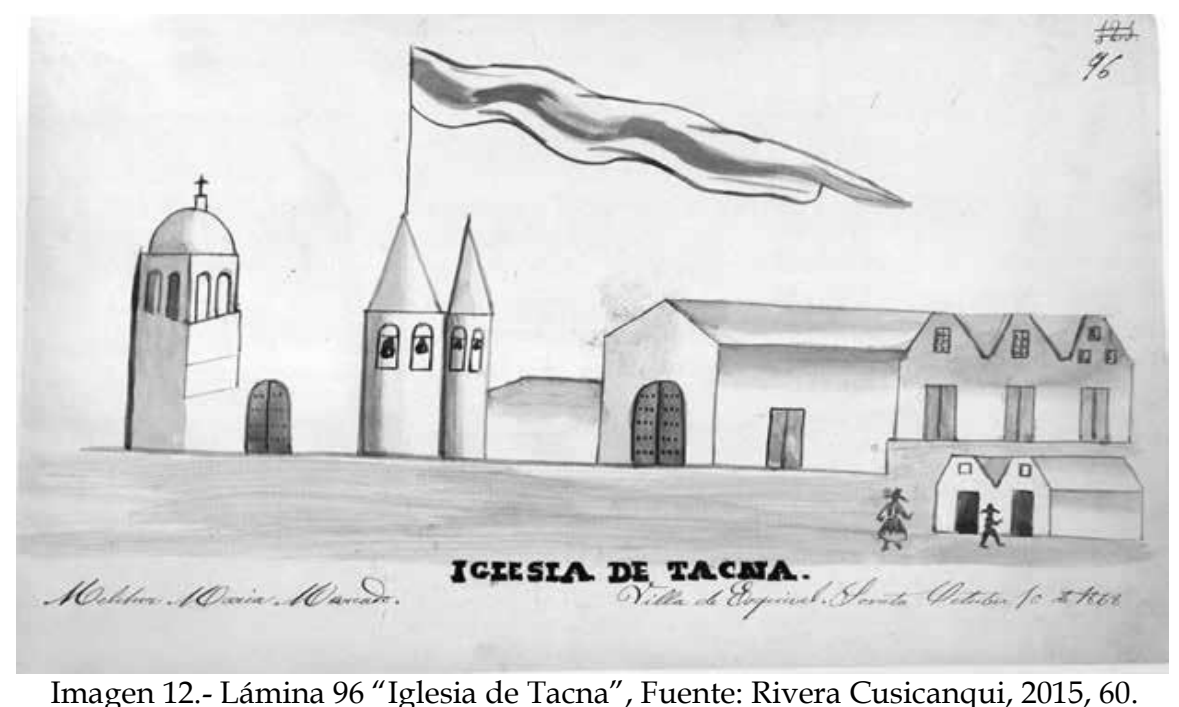

Con este ejercicio Silvia Rivera Cusicanqui analiza lo imperceptible a simple vista de los trazos, líneas, la ubicación de las figuras retratadas. Una vez más el énfasis está en la simbología del dibujo a nivel asociativo, la cual reflejaría una composición que se enriquece en simbolismo a diferencia si estos se vieran de forma aislada.

Retrata las desigualdades de un poderío naval y terrestre así como: "La precariedad del poder republicano, del mismo modo que la no coetaneidad de sus tipos humanos, la no contigüidad entre el mercado interno del país y sus fronteras administrativas, serán trabas contundentes a su anhelo de imaginar una comunidad viable y continua -en el tiempo y el espacio- en ese mapa llamado Bolivia"50. Logra interpretar una de las paradojas en la obra de Melchor, la de reconocer la importancia vertebral del recorrido iglesia-barcos-montañas bolivianas, como circuito costa-altiplano-minas, y cuya lectura se puede realizar desde la obtención del poder republicano que se encuentra en convergencia con la iglesia, demostrando claramente un sesgo conservador.

50 Rivera Cusicanqui, Sociología de la Imagen... op. cit., 54. 


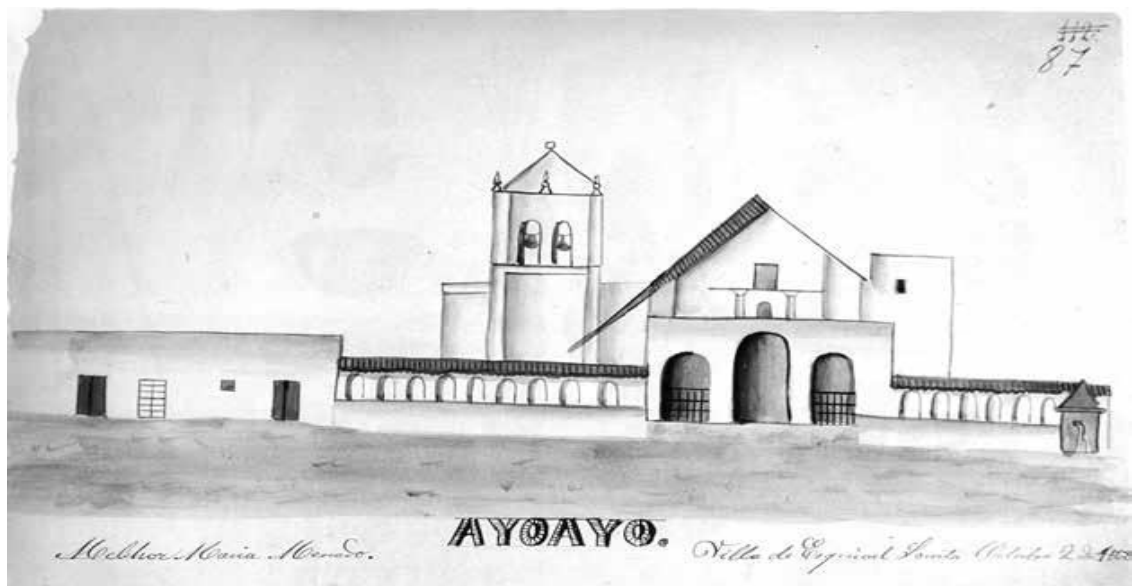

Imagen 13.- Lámina 87 “Ayoayo”, Fuente: Rivera Cusicanqui, 2015, 56.

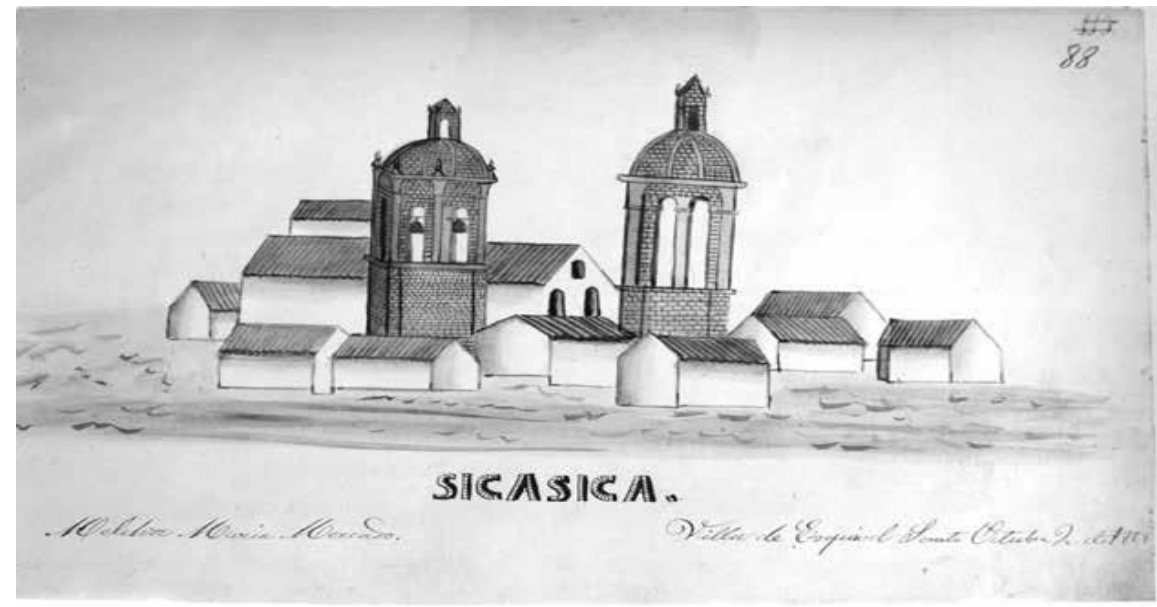

Imagen 14.- Lámina 88 “Sicasica”, Fuente: Rivera Cusicanqui, 2015, 56.

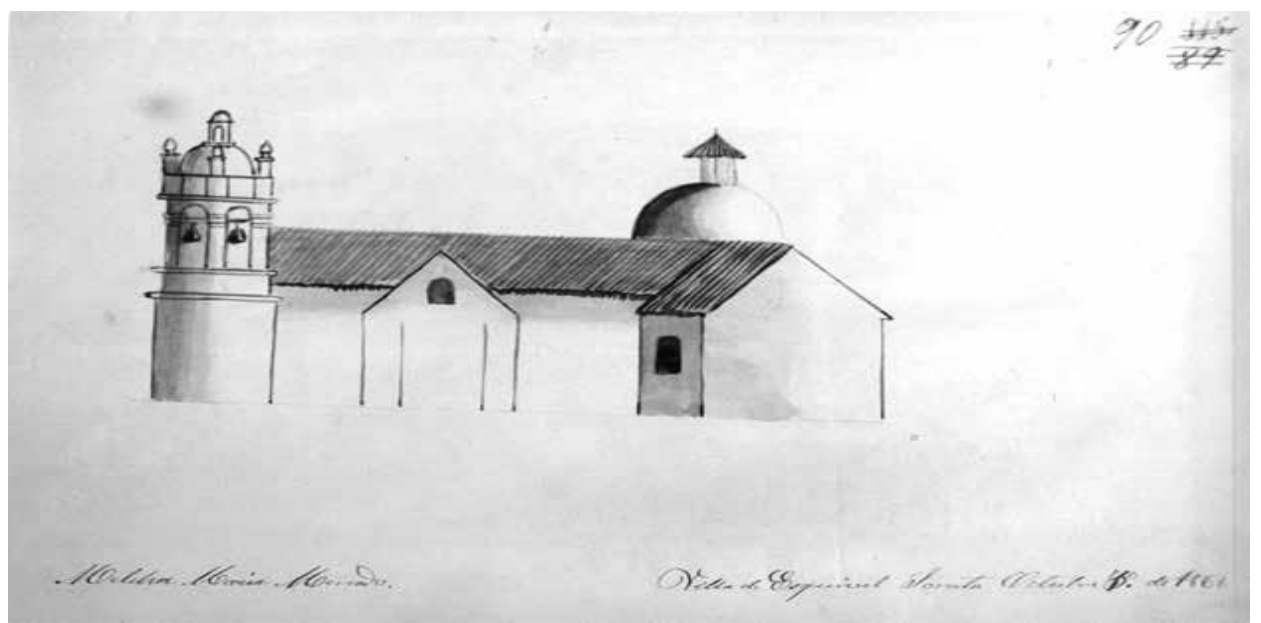

Imagen 15.- Lámina 90 “Iglesia sin nombre. Villa de Esquivel. Sorata (?)”, Fuente: Rivera Cusicanqui, 2015, 57. 


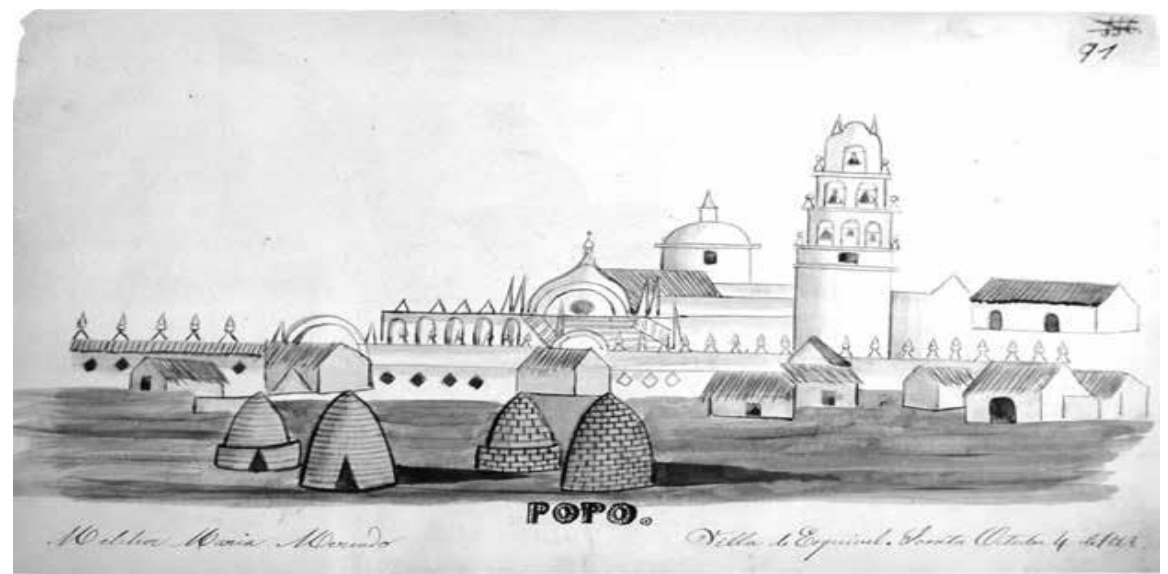

Imagen 16.- Lámina 91 “Popo”, Fuente: Rivera Cusicanqui, 2015, 58.

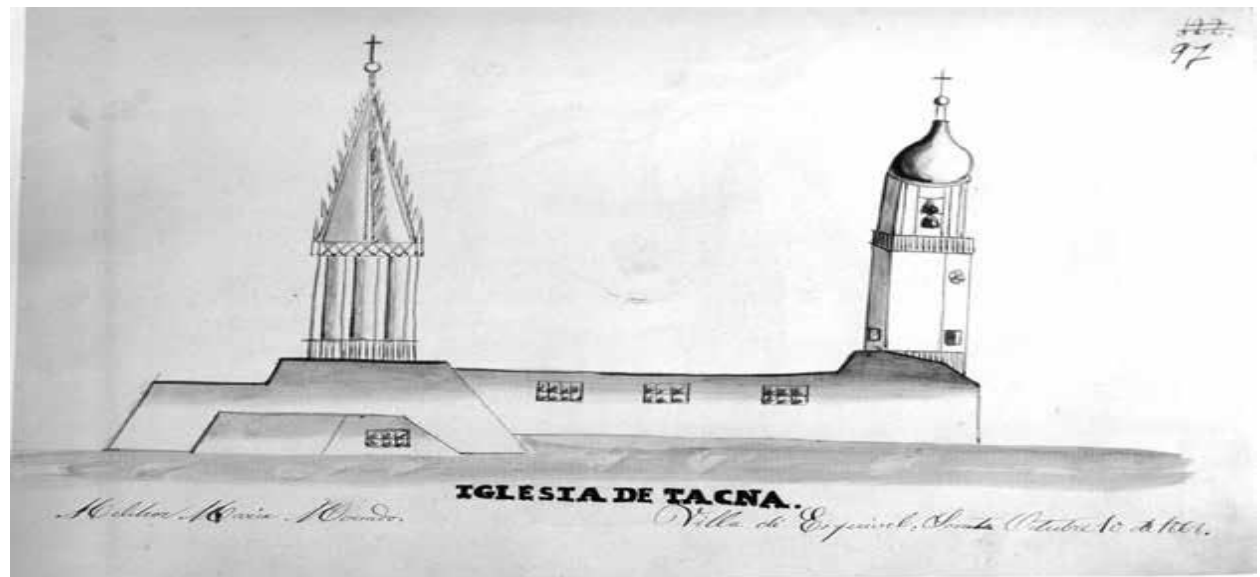

Imagen 17.- Lámina 97 “Iglesia de Tacna”, Fuente: Rivera Cusicanqui, 2015, 61.

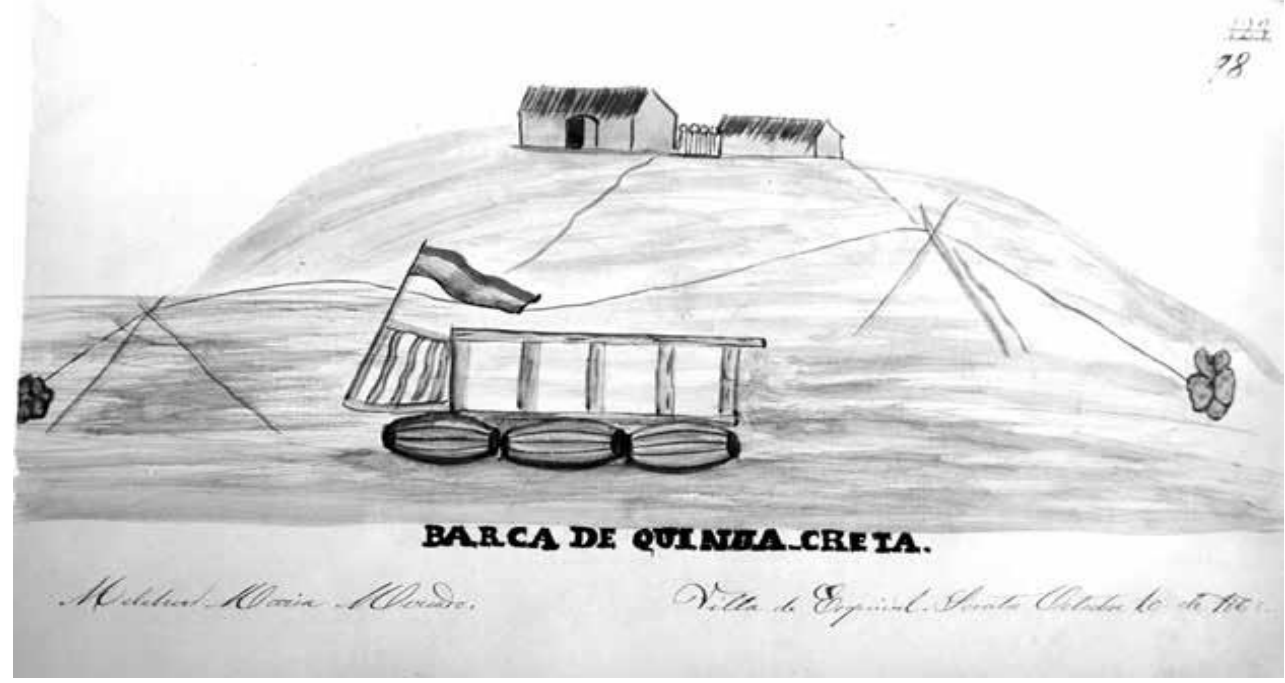

Imagen 18.- Lámina 98 “Barca de quinua. Creta”, Fuente: Rivera Cusicanqui, 2015, 61. 


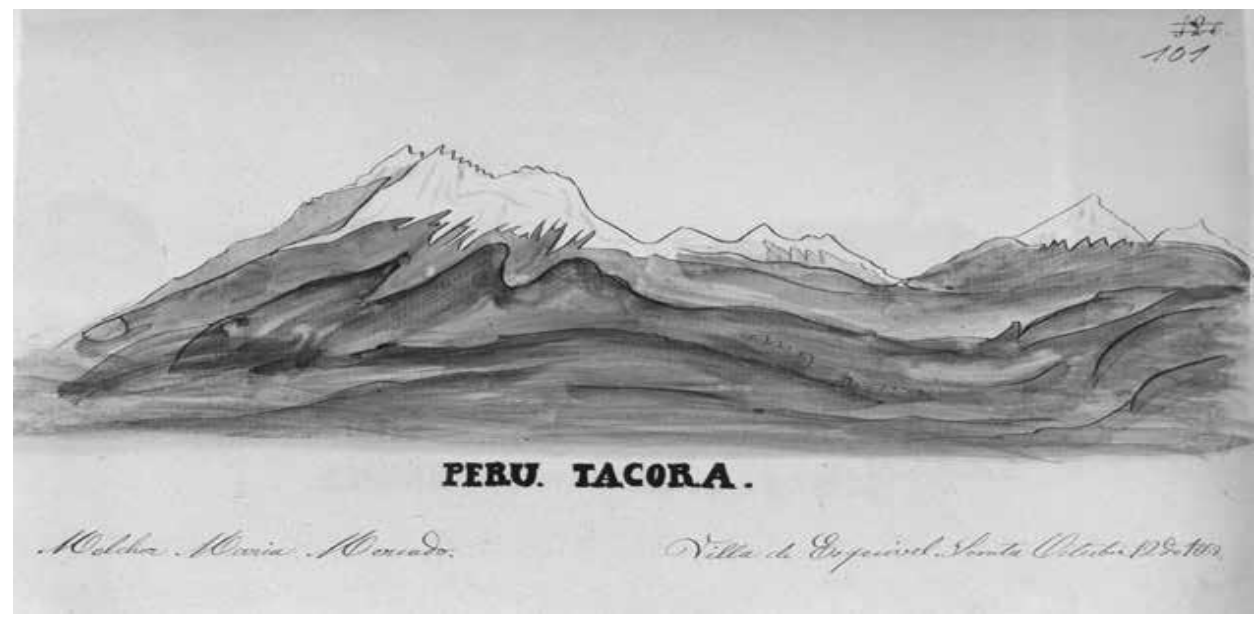

Imagen 19.- Lámina 101 “Perú. Tacora”, Fuente: Rivera Cusicanqui, 2015, 63.

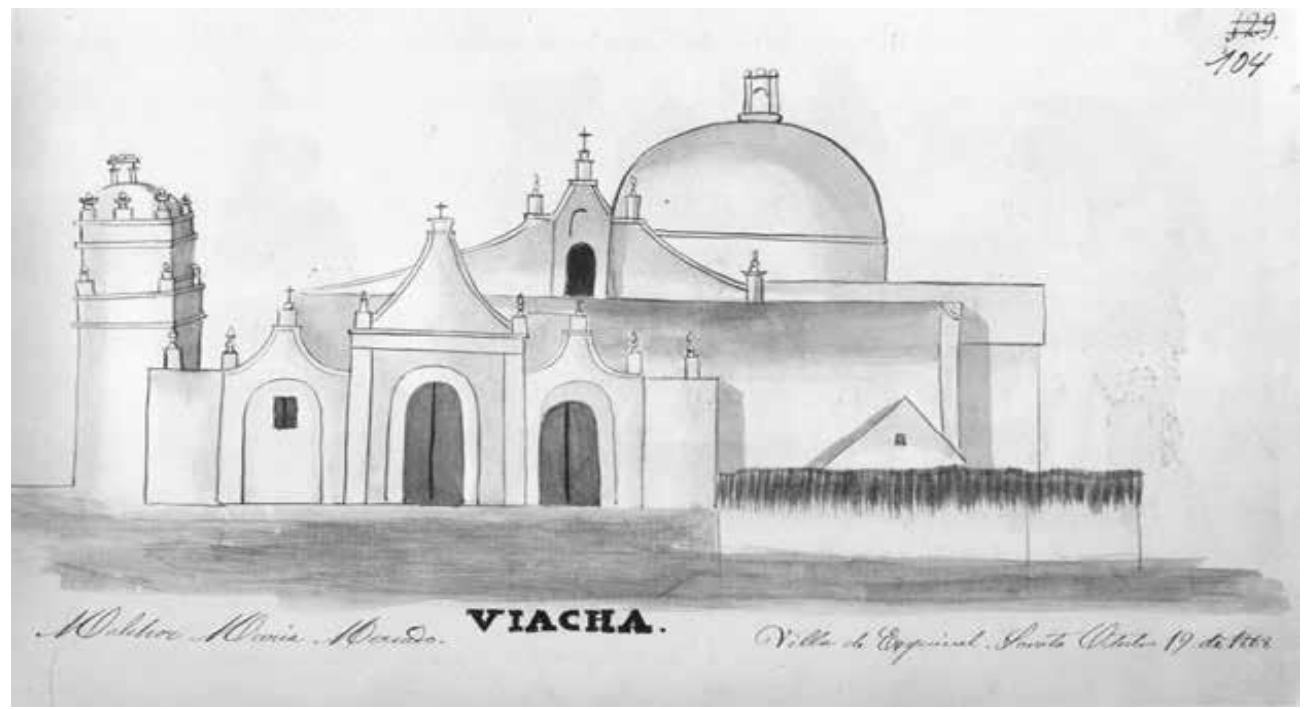

Imagen 20.- Lámina 104 “Viacha”, Fuente: Rivera Cusicanqui, 2015, 64.

En el apartado "Una reflexión sobre la felicidad y la rabia: los últimos cuadros de Sorata", Rivera Cusicanqui analizar la postura de Mercado quien vuelve a graficar a un sujeto dinámico, del trajín, con una pintura moderna y expresiva, terminando con una representación alegórica. Mercado, a juicio de la socióloga, avanza desde un trayecto iglesia-montaña, hacia la representación de paisajes íntimos. Una combinación ética y estética de lo boliviano, donde inmortaliza la naturaleza, con casas e iglesias que se integran a este paisaje natural y cercano con un telón de fondo montañoso. A partir de esta representación, la cumbre esta vez:

“integra un paisaje dominantemente humano y productivo (donde ni siquiera está presente la Iglesia, Lámina 113, o donde lo está de un modo discreto, Lámina 115). Así, Sorata, que podría haberle brindado la confirmación más vivida del poder 
iconográfico de montañas e iglesias, resulta permitiéndole la reconstrucción de un paisaje integrado, presente sólo de modo excepcional en su obra anterior" 51.

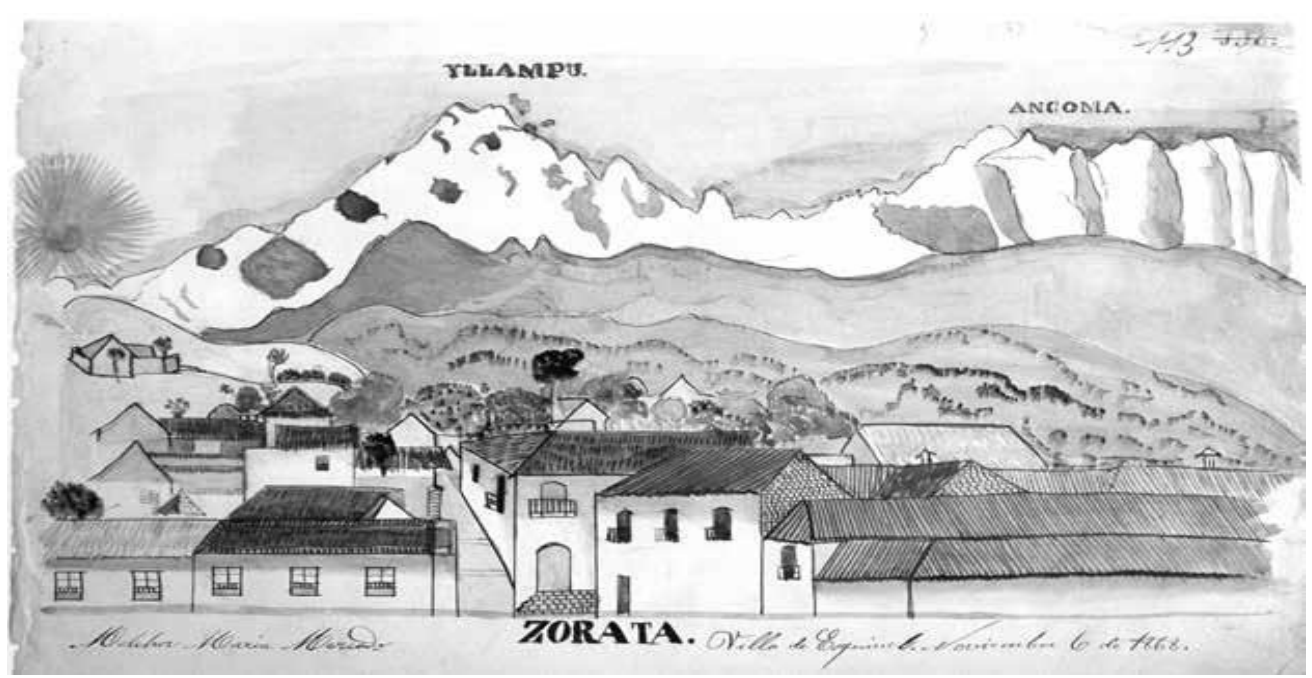

Imagen 21.- Lámina 113 “Zorata”, Fuente: Rivera Cusicanqui, 2015, 67.

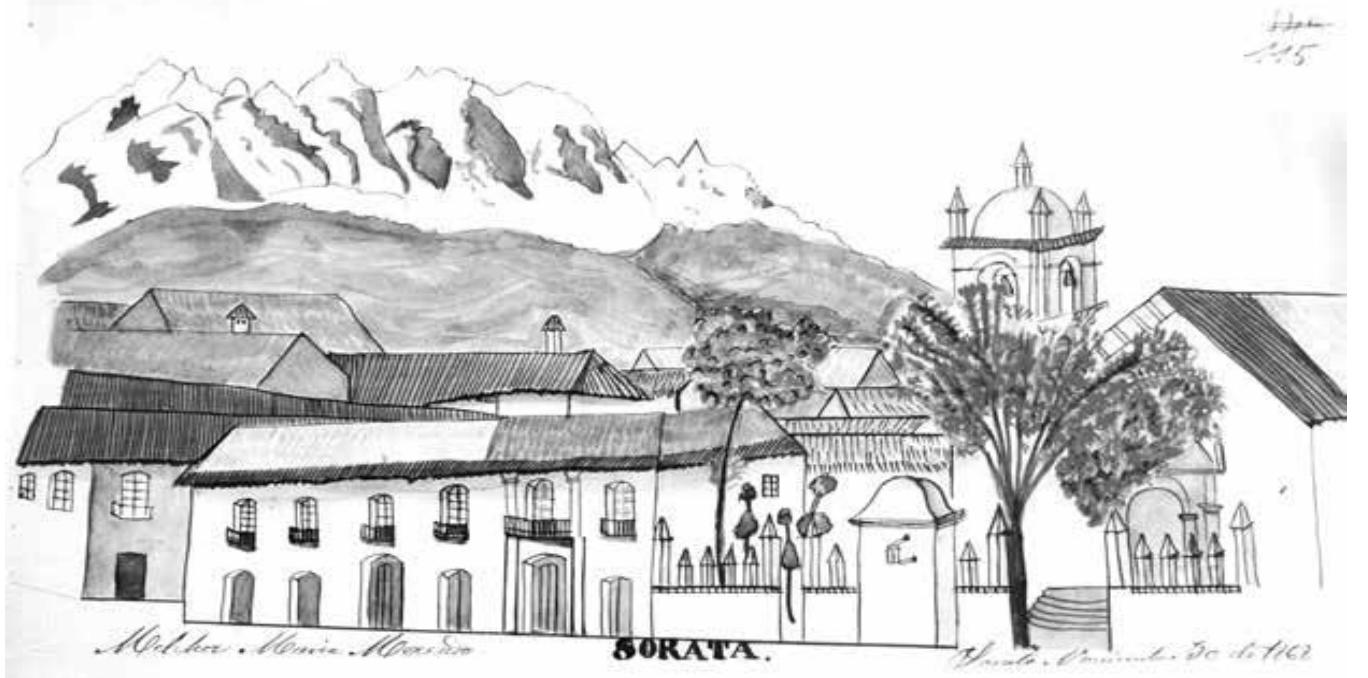

Imagen 22.- Lámina 115 “Sorata”, Fuente: Rivera Cusicanqui, 2015, 68.

Según Rivera, en esta etapa destaca la sensación de un bienestar experimentado por Melchor en Sorata, en la cual existiría una representación de "conformidad con el orden señorial" 52 , que va más allá de lo material y que estaría reflejando un estado de madurez respecto a su etapa de vida.

51 Rivera Cusicanqui, Sociología de la Imagen... op. cit., 65.

52 Ibid., 66. 
Sin embargo, Silvia Rivera Cusicanqui deja abierta la pregunta respecto a la forma cómo esta supuesta paz interior de las secuencias pictóricas, se ve interrumpidas por láminas que evocan: "[...] alegorías de pecados capitales, (Láminas 117-118), donde parece volcar toda la amargura inconsciente por su propio origen e identidad, víctima quizás de vilezas materiales, o amigo consuetudinario del alcohol?"53.

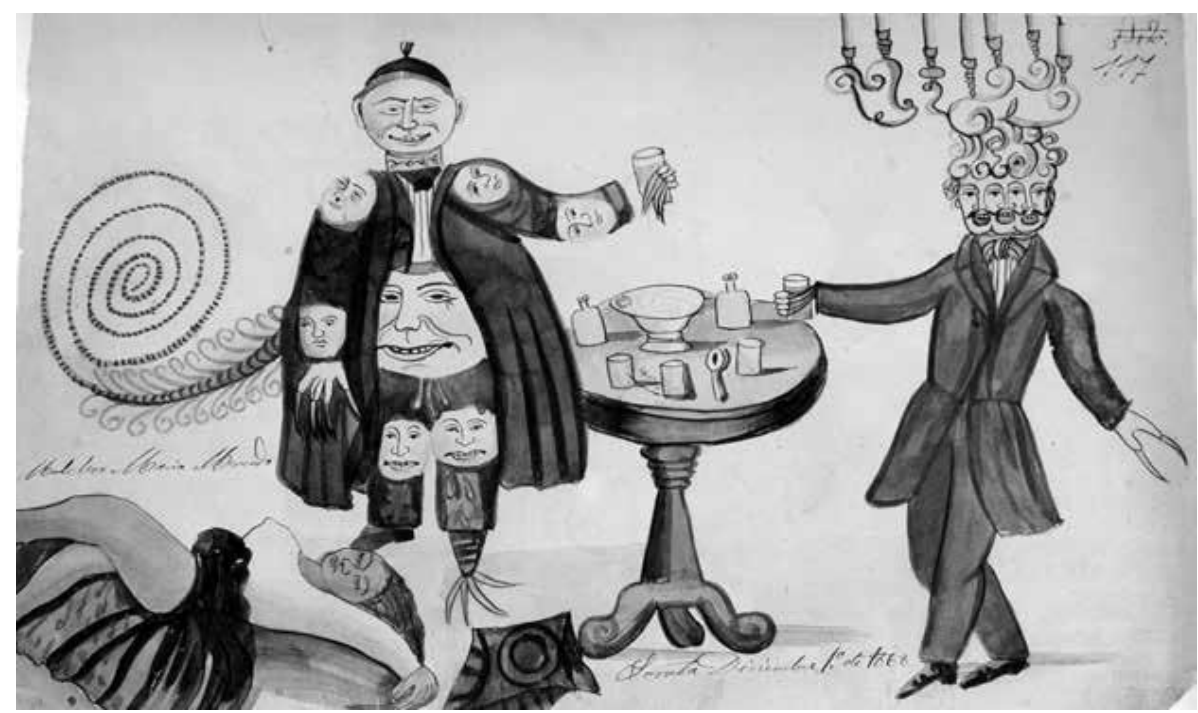

Imagen 23.- Lámina 117 “Los pecados capitales”, Fuente: Rivera Cusicanqui, 2015, 69.

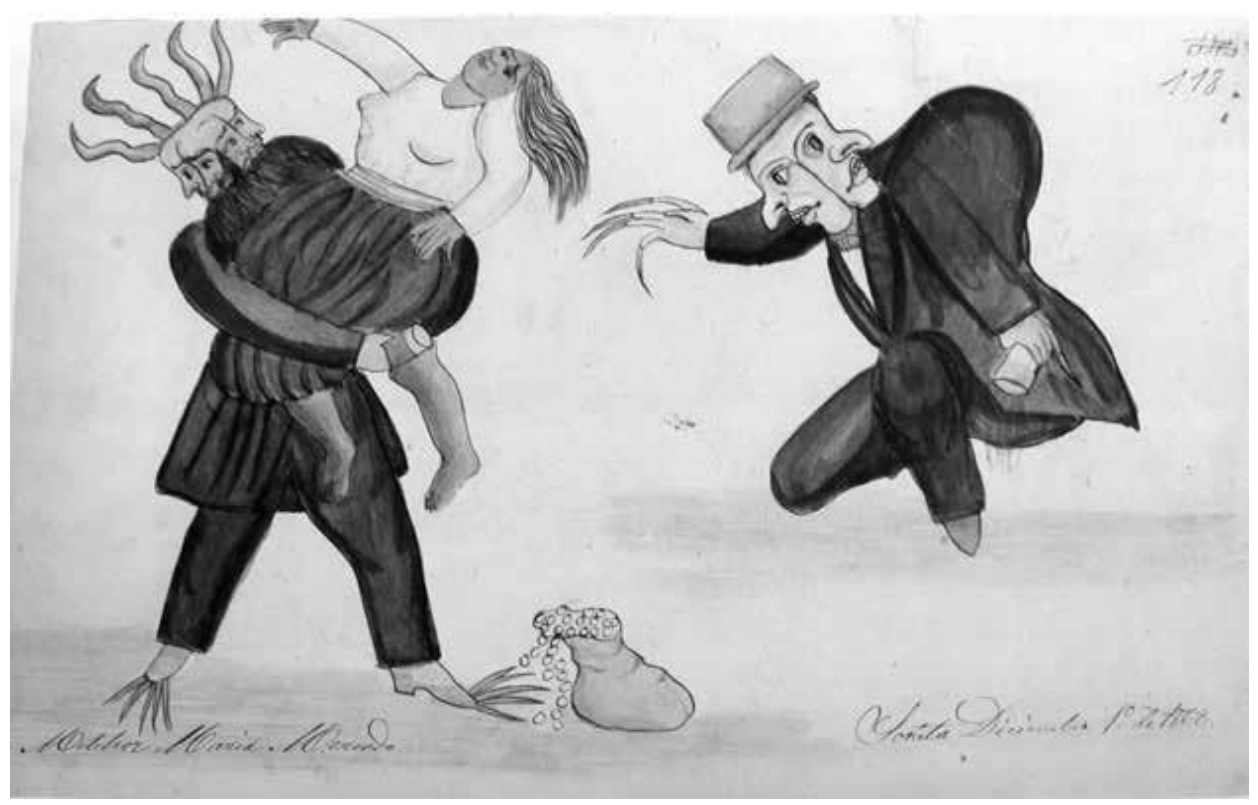

Imagen 24.- Lámina 118 “Los pecados capitales”, Fuente: Rivera Cusicanqui, 2015, 70.

Pareciera ser dice la autora, que la obra de Mercado está reflejando su estado emocional, el cual se vincula con los paisajes, arquitectura, gente y los conflictos políticos

${ }^{53}$ Rivera Cusicanqui, Sociología de la Imagen... op. cit., 66. 
que se erigen en relación con una formación identitaria boliviana "un todo orgánico, en un orden social imaginado, que inaugura una comunidad de seres coetáneos" 54 pero que se constituye en constante conflicto.

En el apartado "Historias Alternativas. Un ensayo sobre dos "sociólogos de la imagen" [1997]", releva la importancia de otras manifestaciones culturales que puedan dar cuenta de una historia no oficial de la comunicación intercultural, -por eso la imagenconnotando la importancia de la configuración sociodemográfica de Bolivia, con altos índices de población indígena, así como el uso de sus diferentes lenguas.

Destaca la tensión entre estas manifestaciones culturales, cuando estas se han expresado desde un origen dominante, vertical, desde el poder y estatus. De esta forma desentraña que: "Un caso entre muchos es el de las pinturas coloniales del barroco andino, ideadas por la Iglesia de la contrareforma como un medio de conversión de los indios al catolicismo, pero que al integrarse a los ritos agrícolas y fiestas patronales, son reinterpretadas en un sentido autónomo y hasta subversivo" 55 .

Por lo cual hace un llamado a analizar estas expresiones pictóricas de la época, desde una visión crítica y alternativa a lo oficial, ya que, está convencida que la sociología de la imagen posee esa capacidad de ver acuciosamente las imágenes que pueden pasar inadvertidas por el ojo común, profundizando así el esfuerzo etnohistórico y semiótico andino de Waman Puma en 1613 al intentar comunicar mediante imágenes al rey de España, los negativos avatares impuestos por virreyes y corregidores entre otros, a quienes Waman califica como "mundo al revés". Desarrolla y analiza parte de la obra del cineasta Jorge Sanjinés y una vez más al pintor Melchor María Mercado, con el objeto de analizar la complejidad de sus obras las que se encuentran marcadas por el devenir histórico de sus épocas a pesar de sus distancias cronológicas entre sí.

De esta forma la autora se acerca a entender la sociología de la imagen en honor a los autores que analiza, planteando que: "no es simplemente una copia o analogon de la "realidad" (cf. Barthes 1995), sino más bien una interpretación de la sociedad de su época, en sus dimensiones abigarradas y conflictivas" 56 .

Pese a algunas críticas que se podrían enarbolar respecto su pertinente comparación a razón de su descontextualización temporal entre la vida de estos autores (Melchor conocido recién gracias a la publicación de su obra en 1991 por Gunnar Mendoza) ambos trabajaron al alero de fuentes orales y "formas no convencionales de investigación etnografía" 57. Así nos lega la importancia de abordar su obra "desde un punto de vista sociológico, en la medida en que la etnografía, la imaginación y la oralidad fueron integradas en sus películas y pinturas, recorriendo caminos paralelos de interpretación y comprensión de la sociedad, en un gesto que sigue siendo válido para iluminar nuestro presente" 58 .

El texto avanza con un análisis de los trabajos fílmicos de Sanjinés, con la preocupación de plasmar el silencio colectivo de la dictadura de Banzer (1971-1978), época

\footnotetext{
54 Rivera Cusicanqui, Sociología de la Imagen... op. cit., 66.

55 Ibid., 73.

56 Rivera Cusicanqui, Sociología de la Imagen ... op. cit., 74.

57 Ibid., 74.

58 Rivera Cusicanqui, Sociología de la Imagen... op. cit., 75.
} 
en la cual toma relevancia de la comunicación aymara, por transformarse en un elemento metafórico y codificado al poder dominante. En estos trabajos se pueden connotar las voces subalternas que viven el momento crítico de ruptura democrática boliviana.

Luego de analizar algunas obras de Sanjinés donde transversalmente se dibujan relatos de opresión, autoritarismo, clasismo, y dominación en relación de a una dominación racial y étnica, en la narrativa de Mercado, tal como Silvia Rivera Cusicanqui califica a su segundo sociólogo de la imagen.

A lo ya mencionado, se suma lo que Mercado expresa en su pintura una tensión entre la historiografía tradicional del siglo XIX como: "una época de crisis, depresión económica y degradación de la población indígena, que sólo sería superada con el crecimiento de la economía exportadora de minerales hacia fines de ese siglo"59. Pese a lo anterior, Mercado expresa en sus acuarelas una sociedad vital, conectada mediante rutas comerciales enriquecidas por relaciones económicas y simbólicas de intercambio a nivel urbano-rural.

En este sentido, Mercado interpreta y retrata lo que una historiografía reciente da cuenta: Una tensión surgida por el dinamismo comercial exportador y a la vez la opresión indígena. Diferente a décadas anteriores en cuya época de supuesta crisis minera, se crearon diversas oportunidades comerciales internas, favoreciendo el mercado regional y la proliferación de mejores tratos y contratos con población indígena. Rivera Cusicanqui analiza como Mercado a través de sus acuarelas, visibiliza lo que la historiografía tradicional invisibiliza: el rol femenino como sujeto económicamente activo. Además de colocar énfasis en otras relaciones comerciales y religiosas que están al alero de la economía minera.

Los ropajes y vestimentas se dibujan a partir de las distinciones étnicas, de clase, de jerarquía racial, en las que el hombre posee una carga tras asumir una expresiva distinción del vestir entre el cholo y el criollo-mestizo europeizado. A su vez, cabe destacar que este tipo de distintivo impacta en el cobro de impuestos propio del trance comercial. Por otro lado, no resulta así en el caso de la mujer, quien se distingue menos en sus vestimentas permitiendo un tránsito más expedito y transversal a la distinción étnica y el comercio, situación que a la larga en el tiempo también pierde sentido, comenzando a distinguirse al igual que en la representación masculina de un vestir estéticamente eurocéntrico.

Rivera escribe según los retratos de Mercado inspirados de Waman Puma de "Mundo al revés" los cuales parecen: "condensar la experiencia catastrófica de la conquista y la colonización, con las fracturas y aporías que se vivieron en el siglo XIX republicano" 60 .

\footnotetext{
59 Ibid., 83.

${ }^{60}$ Rivera Cusicanqui, Sociología de la Imagen... op. cit., 85.
} 


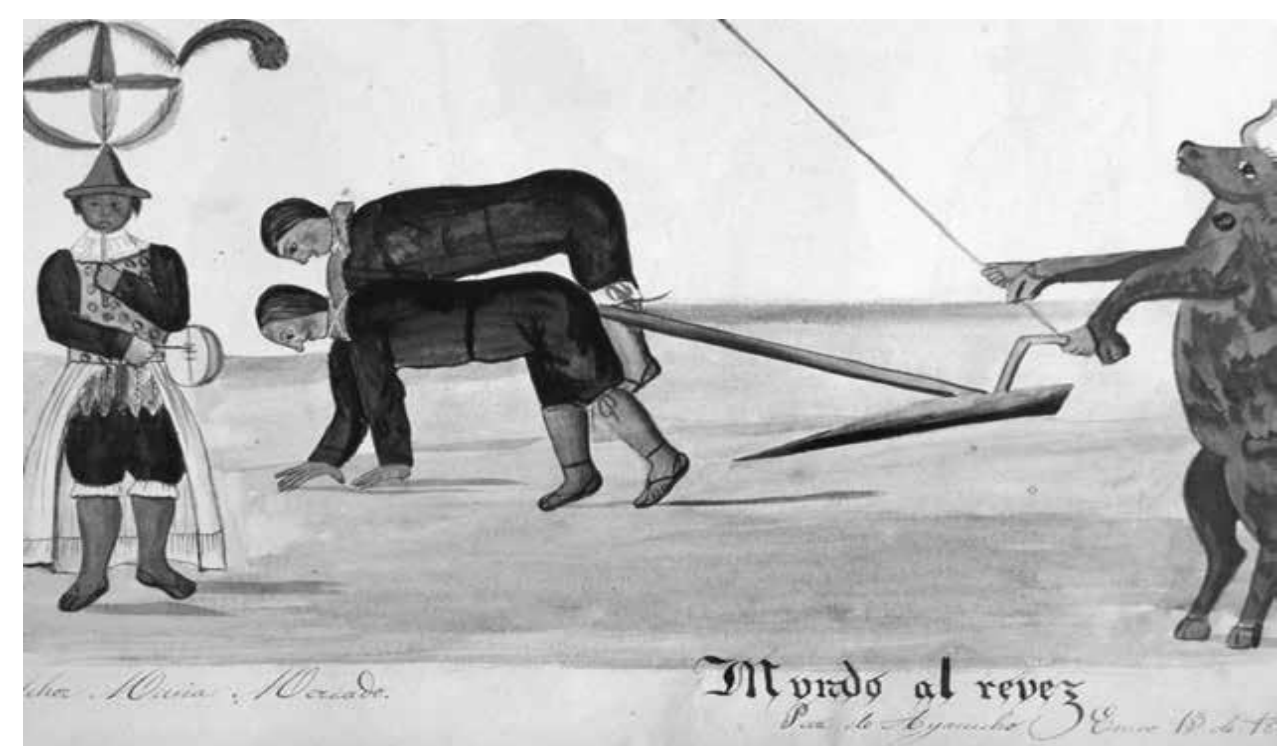

Imagen 25.- "Mundo al Revés. Melchor Maria Mercado”, Fuente: Rivera Cusicanqui, 2015, 86).

“Las alegorías de Melchor María Mercado, tan oscuras como las de Jorge Sanjinés, reflejan un punto de vista pesimista sobre la sociedad boliviana y sus estratos dominantes: la iglesia como nido de corrupción; el sistema judicial marcado por la ambición y la doble moral; un mundo al revés en el que los papeles de trabajadores y bueyes de labranza resultan invertidos. Este es a la vez un diagnóstico lúcido de las brechas entre las normas que regulan la relación entre dominantes y dominados, basadas en ideales republicanos de igualdad y libertad, y aquellas prácticas sociales que reproducen la inequidad, el autoritarismo y la injusticia de modo cotidiano"61.

En el apartado "El potencial epistemológico de las fuentes orales e iconográficas", Silvia Rivera Cusicanqui expresa lo que "Homi Bhabha denomina las "narrativas fragmentadas de la nación" (Babha 1990). En una sociedad colonial como la boliviana, la imagen de una nación moderna posible y deseable está cruzada por fuerzas divisivas como la identidad étnica y la dominación colonial, que discurren por debajo de la aparente igualdad promovida por el mercado, el modelo ciudadano y la democracia" 62.

Aquí, en contraposición con la mirada intelectual liberal, nacionalista o marxista, se propone una comprensión hermenéutica que interprete y reflexiones sobre la nación boliviana, hacia la organización, valores y fuerzas morales que normativizan la sociedad boliviana. Con el estudio de las fuentes iconográficas -nos expone- se plasma mejor la forma de ver el mundo social, más que lo escrito en historiografía o el pensamiento social, el que "tiende a domesticar el pasado -haciéndolo transparente e inteligible- $[\ldots]$ "63. En tanto las expresiones pictóricas:

“apuntan a la irreductibilidad de la experiencia humana, a las grietas y fracturas del ámbito normativo, mostrando cómo las cosas son, en lugar de figurarse cómo

\footnotetext{
61 Ibid., 87.

62 Rivera Cusicanqui, Sociología de la Imagen... op. cit., 88.

63 Idem.
} 
deberían ser. Mientras que la escritura y los marcos conceptuales de la ciencia social convencional tienden a obliterar las voces subalternas o a integrarlas en una narrativa monológica de progreso y modernización, la imagen pictórica o audiovisual reactualiza las fuerzas que dan forma a la sociedad, a tiempo de organizar lo abigarrado y caótico en un conjunto de descripciones "densas" e iluminadoras" 64 .

Rivera Cusicanqui destaca las figuras de Sanjinés y Mercado a razón de un trabajo denunciante donde expresan la presencia de un racismo posterior a la revolución del 1952, cuando se pretende homogenizar la sociedad boliviana con un halo europeizante y norteamericano, apelando al racismo a la colonialidad que se sigue extendiendo en el intento de una modernización boliviana, por ejemplo, a través de las reformas agrarias, educativas y el voto.

“En esta reflexión en torno a las fuentes orales y visuales, me he propuesto analizar el trabajo de dos sociólogos de la imagen que han representado y teorizado sobre la naturaleza y las contradicciones de la sociedad boliviana, desde el punto de vista de su población indígena y trabajadora, recreando un pasado aún vivo y resistente a las fuerzas homogeneizadoras de la modernización eurocéntrica" 65.

El acápite "El mito de la pertenencia de Bolivia al "mundo occidental". Réquiem para un nacionalismo", comienza con un desarrollo sociopolítico previo a la revolución de 1952. En este sentido, Silvia Rivera coloca sobre la mesa las condiciones sociales, económicas y políticas que anteceden a la revolución, para luego y en honor a los intereses de este trabajo, centrarnos en la imagen.

De esta forma en el apartado "La reinvención de la historia", Rivera Cusicanqui analiza el Álbum de la Revolución de Fellman Velarde del año 1954. Un álbum con 159 fotos de la revolución de 1952, con un potente hito que refiere a la nacionalización de las minas. Este compendio de fotografías posee pocas referencias, es más bien un esfuerzo por plasmar en imágenes la exitosa revuelta. Así pretende publicitar y difundir un camino de identidad nacionalista con particulares características que Silvia Rivera Cusicanqui analiza discursivamente.

Nuestra socióloga boliviana en este apartado, analiza con destreza científico social las imágenes. Describiendo con maestría interpretativa y holística las fotografías, sin dejar de lado una revisión histórica de los acontecimientos lo que enriquece cada imagen invitando a comprender estos episodios plasmados en fotografías.

Silvia Rivera no pasa por alto a quienes no figuran en este álbum fotográfico: "indios y mujeres. Estas poblaciones mayoritarias, a través de sus luchas, revelan las contradicciones diacrónicas de larga duración entre la élite colonial dominante, de origen europeo, y las masas subalternas indígenas y cholas" 66 . Actores que pasan a ser elementos culturales ornamentales del registro, de un álbum que pretende generar una representación occidentalizada, patriarcal y cristiana de los acontecimientos.

\footnotetext{
64 Rivera Cusicanqui, Sociología de la Imagen... op. cit., 88, 89.

65 Ibid., 91.

66 Rivera Cusicanqui, Sociología de la Imagen... op. cit., 145.
} 
“Esta noción le permite a las clases dominantes objetivar y subalternizar a estas poblaciones, y legitimar el clientelismo como nuevo modo de dominación anclado en redes escalonadas y verticales de manipulación y dominio" 67 . Esto representa para Silvia Rivera, el sentido cultural y civilizatorio como proyecto largo plazo que ha caracterizado la dominación interna boliviana. Resulta interesante desentrañar desde el texto para los fines de este artículo que, a modo de ejemplo teórico-aplicado -utilizando el álbum de la revolución- pretende responder a las siguientes interrogantes:

“¿Cómo se construyó esta versión masculinizada y mestiza de la historia de las moviliaciones populares en Bolivia? ¿Cómo afectó esta representación a las realidades sociales y a las formas organizativas concretas de la población popular y productiva? ¿De qué manera fue funcional a esta construcción la idea de "miseria" y la de "atraso" en la visión de las capas intelectuales mestizas del partido triunfante?" 68 .

En definitiva, escribe Rivera Cusicanqui, las fotos corresponden a un intento por levantar un imaginario nacional que se masculinizó, elitizando el hito de insurrección popular "amoldándola a una imagen ciudadana de corte mestizo, moderno y masculino" 69. En este sentido el discurso es "miserabilista", objetivando la figura de indios y mujeres que son sometidos a la explotación, transformándolos en anonimatos colectivos y colonizados, privándolos de su condición de sujeto histórico. Lo anterior se plasma en una edición y montaje fotográfico que aporta a este anonimato del pueblo indígena, cholo y mestizo, cuya selección de fotos, encuadres y notas a pie, homogenizan la historia contemporánea de Bolivia. Se les moldea como una ciudadanía sumisa, subordinada a una figura que se enarbola iconográficamente como un caudillo visionario y constructor de la revolución (refiriéndose a Víctor Paz Estenssoro del Movimiento Nacionalista Revolucionario MNR).

Silvia Rivera hace un llamado a analizar las secuencias fotográficas con una necesaria mirada crítica, ya que, el uso de fotografías contribuye a generar representaciones e imaginarios que en el caso boliviano resultan perjudiciales para los desposeídos y los paisajes, a los cuales se les acuñan comentarios con una racionalidad teleológica según su encuadre fotográfico. En este sentido, destaca el juego de los contrastes del montaje fotográfico, en el cual el indígena y cholo es el desfavorecido, el anónimo y un sujeto de explotación.

67 Ibid., 145, 146.

68 Rivera Cusicanqui, Sociología de la Imagen... op. cit., 150.

${ }^{69}$ Rivera Cusicanqui, Sociología de la Imagen... op. cit., 151. 


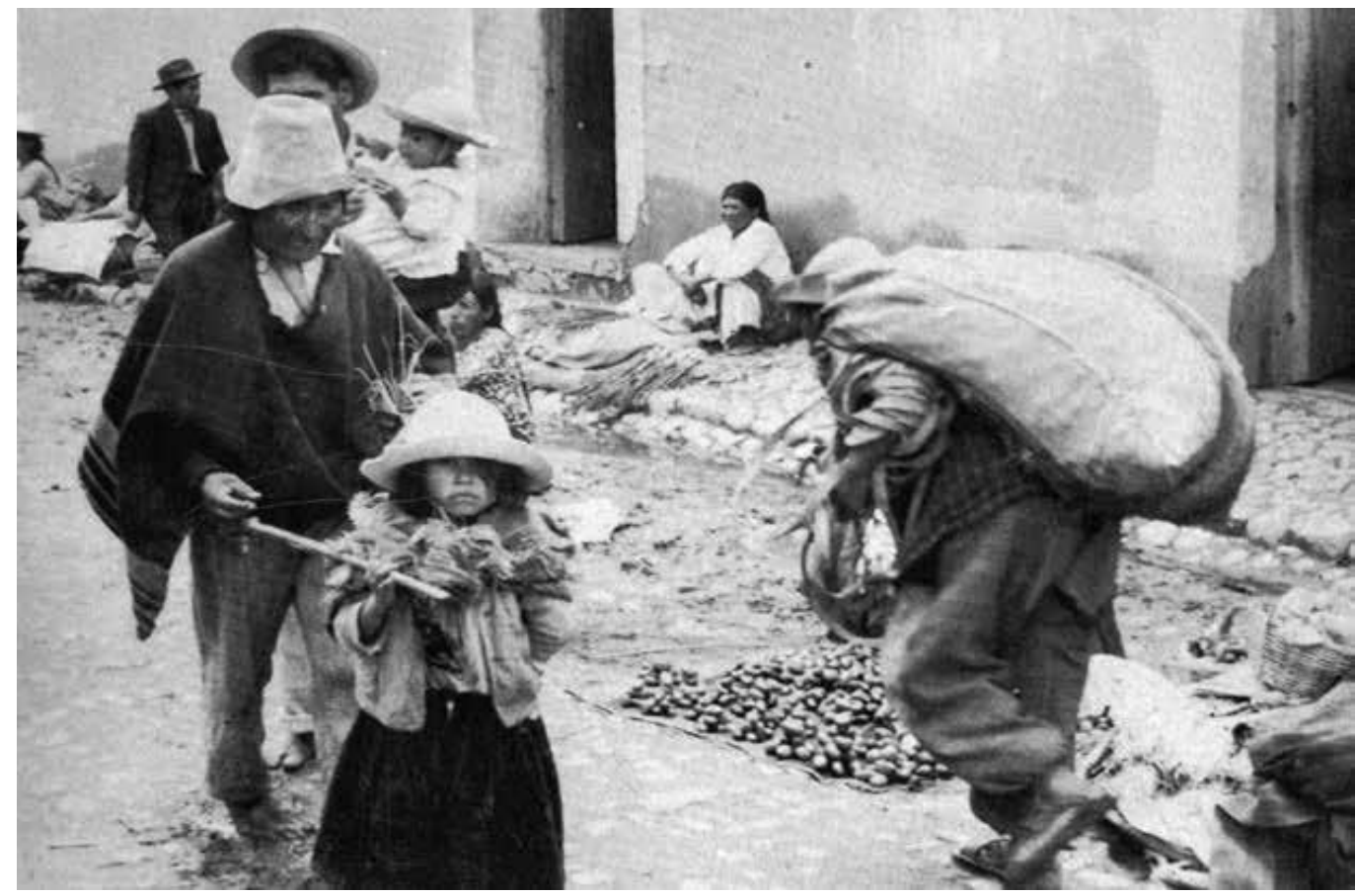

Imagen 26.- “Ilustración 1", Fuente: Rivera Cusicanqui, 2015, 156.
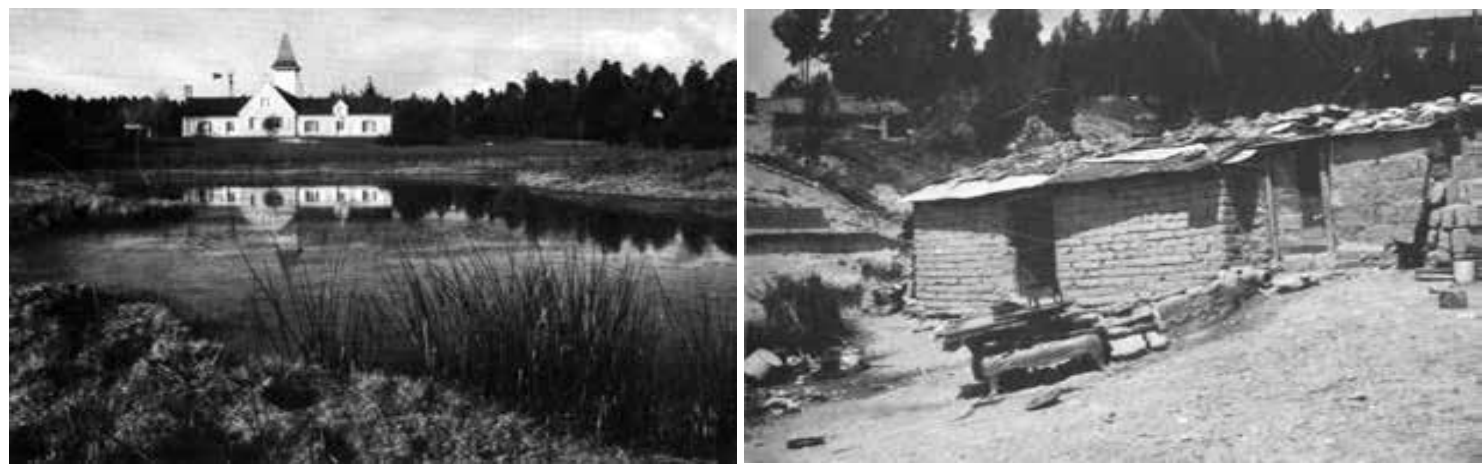

Imagen 27.- “Ilustración 5", Fuente: Rivera Cusicanqui, 2015, 157.

\section{Conclusión}

La sociología de la imagen es una sub disciplina que se nutre epistemológica, teórica, metodológica y técnicamente, por variados otros recursos disciplinarios, rompiendo de esta forma las fronteras disciplinarias de las ciencias sociales y apostando a una contingente necesidad transdisciplinar que permita comprender de mejor formas realidades sociales y culturales que, a su vez, posean una pretensión explicativa debido a la recursividad del análisis histórico y dialéctico que Silvia Rivera Cusicanqui asume epistemológicamente.

De esta forma podemos configurar estrategias analíticas, y técnicas que desde la triangulación analítica puedan valorizar las miradas y la emergencia de información y 
datos que a partir de una particular metodología o técnica haría perder valor científico social. En este sentido, aspectos cualitativos, cuantitativos o mixtos de investigación social, así como técnicas de análisis de contenido, análisis del discurso, teoría fundamentada, grupos de discusión, observaciones a través de fuentes secundarias, orales, teatrales, pictóricas, etc. permiten un abordaje holístico de la imagen contribuyendo a una lectura comprensiva de la realidad social, una perspectiva estética cuya mirada debe ser desde la transversalidad histórica como elemento relevante para esta compresión.

Ahora en términos metodológicos ¿Qué riesgo existe en esta sub disciplina respecto a la validez de dichas fuentes? La respuesta no amerita, porque al margen del enfoque metodológico y sus técnicas aplicadas, la postura epistémica es crítica, por tanto, asume como eje principal la transformación social.

La imagen puede perfectamente ser leída como discurso, en el cual emerge del sometimiento colonizador quien asume una posición superior dentro de la verticalidad de estatus social. La imagen se revela ya no como elemento ornamental y "pintoresco", sino más bien como una imagen con voz que pretende ser escuchada y visibilizada, una voz que posee una disposición a la recuperación de su campo social usurpado, sometido, una noción que tiende hacia lo libertario.

Podemos dar cuenta de un esfuerzo kantiano en términos epistemológicos y metodológicos que, a su vez, dista de una pretensión epistémica unificadora y sintética. Lo anterior, a razón de reconocer una tensión teórico conceptual que emerge entre la voz subalterna y la cultura dominante, lo que permite no perder de vista una perspectiva teórica decolonial, de conflicto y que discuta las clásicas categorías conceptuales dicotómicas.

En definitiva, la sociología de la imagen para ella se erige como una sub disciplina que en términos teleológicos pretende desentrañar a través de la imagen como recurso simbólico, aspectos históricamente normativizados por la cultura dominante y que, en este sentido, atenta contra lo subalterno, sus significados, su cotidianeidad, la configuración de representaciones sociales y arquetipos colectivos. La sociología de la imagen se transforma en una perspectiva teórica y metodológica válida, por la cual visibilizar conflictos sociales del pasado subsumidos por el poder dominante y que son atravesados históricamente hacia el presente y proyección futura para la reflexión social desde los propios sujetos, gracias a la pretensión explicativa de la historia en esta reflexión.

Según lo anterior, la sociología de la imagen necesita del conocimiento histórico a partir de una perspectiva crítica y por tanto transformadora, que permita una comprensión dialéctica sociológica y antropológica, abordando a nivel holístico en términos sociales, políticos y económicos la imagen en su contexto. Esto permitirá analizar en profundidad las relaciones entre los pueblos, las representaciones simbólicas, su lenguaje y configuraciones estructurales que permiten reconstruir sociológica e históricamente un valor estético que denota un desafío metodológico.

Para lo anterior, las estrategias de abordaje son multidisciplinarias, privilegiando el análisis del discurso crítico para la reflexión del sujeto en su medio, y a través del diálogo que permita la construcción del conocimiento y la reflexión como un acto pedagógico y liberador. 


\section{Bibliografía}

Accossatto Romina, "Colonialismo interno y memoria colectiva. Aportes de Silvia Rivera Cusicanqui al estudio de los movimientos sociales y las identificaciones políticas", Economía y Sociedad, XXI, (36), 2017, 167-181.

Barthes Roland, Lo obvio y lo obtuso. Imágenes, gestos, voces, Barcelona, Paidos, 1995.

Cacopardo Ana, "Nada sería posible si la gente no deseara lo imposible. Entrevista a Silvia Rivera Cusicanqui", Andamios, 15, (37), 2018, 179-193.

Parra Héctor, "La sociología de la imagen como anclaje crítico descolonizador. Aportes desde el movimiento indianista katarista de Bolivia", Extravío. Revista electrónica de literatura comparada, 8, 2015, 58-71.

Pérez Carlos, Sobre un concepto histórico de ciencia, Santiago, Ediciones LOM, 1998.

Ritzer George, Teoría sociológica clásica, Madrid, Mc Graw Hill, 2001.

Rivera Cusicanqui Silvia, "Construcción de imágenes de indios y mujeres en la iconografía post 52: el miserabilismo en el Álbum de la Revolución", T'inkazos, (19), 2005, 133-156.

Rivera Cusicanqui Silvia, Invisible Realities: Internal Markets and Subaltern. Identities in Contemporary Bolivia, Amsterdam/Quezon City, SEPHIS-SEASREP, 2005.

Rivera Cusicanqui Silvia, "Décoloniser la sociologie et la société", Journal des anthropologues, (110-111), 2007, 249-265.

Rivera Cusicanqui Silvia, Ch'ixinakax utxiwa: una reflexión sobre prácticas y discursos descolonizadores, Buenos Aires, Tinta Limón, 2010.

Rivera Cusicanqui Silvia, "Experiencias de montaje creativo: De la historia oral a la imagen en movimiento". En Silvia Rivera Cusicanqui, Violencias (re) encubiertas en Bolivia, 225-233, La Paz, Piedra Rota, 2010b.

Rivera Cusicanqui Silvia, "Reflexiones en torno a la presente edición". En Silvia Rivera Cusicanqui, Violencias (re) encubiertas en Bolivia, 25-30, La Paz, Piedra Rota, 2010c.

Rivera Cusicanqui Silvia, "Experiencias de montaje creativo: de la historia oral a la imagen en movimiento ¿Quién escribe la historia oral?", Chasqui. Revista Latinoamericana de Comunicación, (120), 2012, 14-18.

Rivera Cusicanqui Silvia, Sociología de la Imagen: Miradas ch'ixi desde la historia andina, Buenos Aires, Tinta limón, 2015.

Rivera Cusicanqui Silvia, "I Love the Mountain", Afterall, 44, 2017, 144-149.

Rivera Cusicanqui Silvia \& El colectivo (dirección), Principio Potosí Reverso, Madrid, Museo Nacional Reina Sofía, 2010.

Rivera Cusicanqui Silvia \& Aillón Soria Virginia, "Introducción. Desde los márgenes. Pensadoras y pensadores bolivianxs de la diáspora". En Silvia Rivera Cusicanqui, \& Virginia Aillón Soria, Antología del pensamiento crítico boliviano contemporáneo, 13-39, Buenos Aires, CLACSO, 2015.

Rivera Cusicanqui Silvia \& de Sousa Santos Boaventura, "Conversa del mundo", En Boaventura de Sousa Santos, Revueltas de indignación y otras conversas, 80-123, Bolivia, ALICE, 2015.

Stocco Melisa, “El concepto de taypi ch'ixi como aporte al estudio de la poesía mapuche bilingüe". Mundo Amazónico, 9, (1), 2018, 87-103. 
Thomson Sinclaire, "Claroscuro andino: Nubarrones y destellos en la obra de Silvia Rivera Cusicanqui", En Silvia Rivera Cusicanqui, Violencias (re) encubiertas en Bolivia, 7-23, La Paz, Piedra roja, 2010.

Wrigth Mills Charles, La imaginación sociológica, México D.F, F.C.E, 1986.

\section{Referencias electrónicas}

Rivera Cusicanqui Silvia, Dis/Locating Culture: Narratives and Epistemologies of Displacement. A stroll through the Colonial Library", 9, Huston, Rice University, 2011, Consultado 12 de junio de 2019. Disponible en:

https://www.academia.edu/7338101/A_stroll_through_the_Colonial_Library 